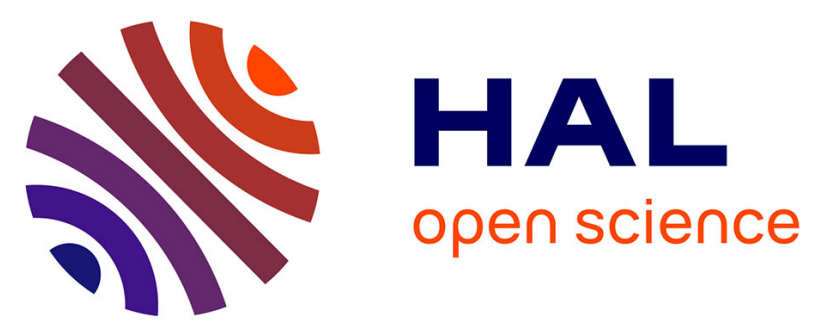

\title{
Pull-apart emplacement of the Margeride granitic complex (French Massif Central). Implications for the late evolution of the Variscan orogen.
}

Jean-Yves Talbot, Michel Faure, Yan Chen, Guillaume Martelet

\section{- To cite this version:}

Jean-Yves Talbot, Michel Faure, Yan Chen, Guillaume Martelet. Pull-apart emplacement of the Margeride granitic complex (French Massif Central). Implications for the late evolution of the Variscan orogen.. Journal of Structural Geology, 2005, 27, pp.1610-1629. 10.1016/j.jsg.2005.05.008 . hal00023495

\section{HAL Id: hal-00023495 \\ https://hal-insu.archives-ouvertes.fr/hal-00023495}

Submitted on 29 May 2006

HAL is a multi-disciplinary open access archive for the deposit and dissemination of scientific research documents, whether they are published or not. The documents may come from teaching and research institutions in France or abroad, or from public or private research centers.
L'archive ouverte pluridisciplinaire HAL, est destinée au dépôt et à la diffusion de documents scientifiques de niveau recherche, publiés ou non, émanant des établissements d'enseignement et de recherche français ou étrangers, des laboratoires publics ou privés. 


\title{
Pull-apart emplacement of the Margeride granitic complex (French Massif Central). Implications for the late evolution of the Variscan orogen
}

\author{
Jean-Yves Talbota, Michel Faurea a, Yan Chena and Guillaume Marteleṭ
}

alnstitut des Sciences de la Terre d'Orléans, UMR 6113, Université d 'O réans, BP 6759, 45067 Orléans Cedex 2, France

bBureau de Recherches Géologiques et Minières, BP 6009, 45060 Orléans Cedex 2, France

\begin{abstract}
A microstructural, magnetic fabric and gravity study is performed on the Carboniferous Margeride granitic complex that crops out in the central part of the Variscan French Massif Central. This complex consists of three facies, namely, a main porphyritic monzogranite, a two-mica granite, and late leucogranite dykes and stocks. In spite of local variations, the magnetic lineation mainly trends NW-SE with a shallow plunge throughout the complex. The magnetic foliation pattern is more complex with various strikes and generally a moderate dip. This fabric pattern complies with the late-orogenic NW-SE regional extensional deformation already recognised in this part of the Variscan Belt. New gravity measurements complete available data and are used to build up a gravity map and a cross-section with which four gravity minima are identified. Three gravity minima are interpreted as extensional fractures consistent with a NW-SE maximum stretching. The last gravity low corresponds to an extensional jog between the two westernmost fractures. The structural and gravity features of the complex are used to propose a feeding and emplacement model controlled by the regional late-orogenic extensional tectonics. The Margeride complex is interpreted as a kilometrescale laccolith-like pluton emplaced in a transtensional setting controlled by
\end{abstract}


a NW-SE opening direction. Such a model strengthens the relationships between pluton emplacement and late-orogenic collapse of the Variscan Belt.

Keywords : Anisotropy of magnetic susceptibility (AMS); Granitic pluton; Extensional tec tonic s; French Massif Central; Margeride pluton

\section{Introduction}

The internal fabric of granite plutons is now routinely used to determine the magmatic processes occurring in crystallising magma chamber and also, in some cases, to determine if regional deformation prevailed during the emplacement and crystallisation of the magma (Gleizes et al., 1997, Benn ef al., 1998, Benn et al., 1999, Benn et al., 2001, Cruden et al., 1999, Becker et al., 2000, Bolle et al., 2003 and Neves et al., 2003). Such studies are made easier by the use of the anisotropy of magnetic susceptibility (AMS) method, which allows a fast and accurate measurement of the magnetic fabrics of plutons (Tarling and Hrouda, 1993 and Bouchez, 1997). Granite bodies can be very useful as kinematic markers, since they may record structural features during a short time interval allowing an accurate reconstitution of the tectonic evolution of orogenic belts (Gleizes et al., 1997 and Benn et al., 2001). However, since fabrics are often acquired quite late during the crystallisation process of granite, the internal fabric is less helpful to characterise the emplacement mechanisms of plutons (Paterson et al., 1998). In addition, the knowledge of the 3D shape of a pluton can bring important information on the emplacement process, for example by locating and characterising the likely feeder zones (Brun et al., 1990, Vigneresse, 1990, Aranguren et al., 1996 and Améglio et al., 1997). Several studies illustrate the usefulness of combining gravity and structural data when investigating the emplacement mode and structural evolution of a granite pluton (Améglio et al., 1997, Vigneresse and Bouchez, 1997 and Ialbot et al., 2004). 
During Middle and Late Carboniferous times, numerous plutons emplaced in the Variscan Belt of the French Massif Central attest to a significant crustal melting event resulting from the Early to Middle Carboniferous nappe stacking (Duthou et al., 1984 and Downes et al., 1997). This granitic magmatism occurred mainly during the last stages of the compressional event or during the late-orogenic extensional collapse (Duthou et al., 1984 and Faure, 1995). Both events begin earlier in the northern part of the massif than in the southern part (Faure, 1995). The southward shifting with time of the two deformation events is still not accurately constrained. Moreover, these two events are partly synchronous; the extensional event begins in the northern part of the massif, whereas the southern part is still in compression. The change from the compressional tectonic event to the extensional tectonic regime must be investigated in more detail in order to understand the evolution of the Variscan Belt.

This study, based on the combined results of several methods, such as field and microstructural observations, low-field AMS measurements and gravity data modelling, was carried out on one of the largest pluton of the French Massif Central, namely the Margeride granitic complex, located in the central part of the French Massif Central (Fig. 1). This complex consists of several granitic bodies with distinct facies emplaced at the end of the Variscan Orogeny when the two tectonic events, extensional and compressional, occur in the northern and southern parts of the massif, respectively. The choice of the Margeride complex as a study area is supported by: (1) the central location of this granitic complex in the Massif Central between the northern and southern parts of the massif, (2) the large size of the granite body, and (3) the occurrence of two facies that emplaced in an interval of about $10 \mathrm{Ma}$. The location and the period of emplacement of these facies allow us to investigate the change of tectonic deformation in the Massif Central. The aim of this study is to better constrain the internal structure and the emplacement processes of this granitic complex bringing new insights not only on the late-orogenic tectonic evolution of the French Massif Central, but 
also on the mechanisms controlling the emplacement of such large plutons. Our feeding and emplacement model is different than that previously proposed for this pluton (Couturié, 1977, Labove, 1982 and Feybesse et al., 1995) in the sense that emphasis is placed here on an extensional tectonic setting.

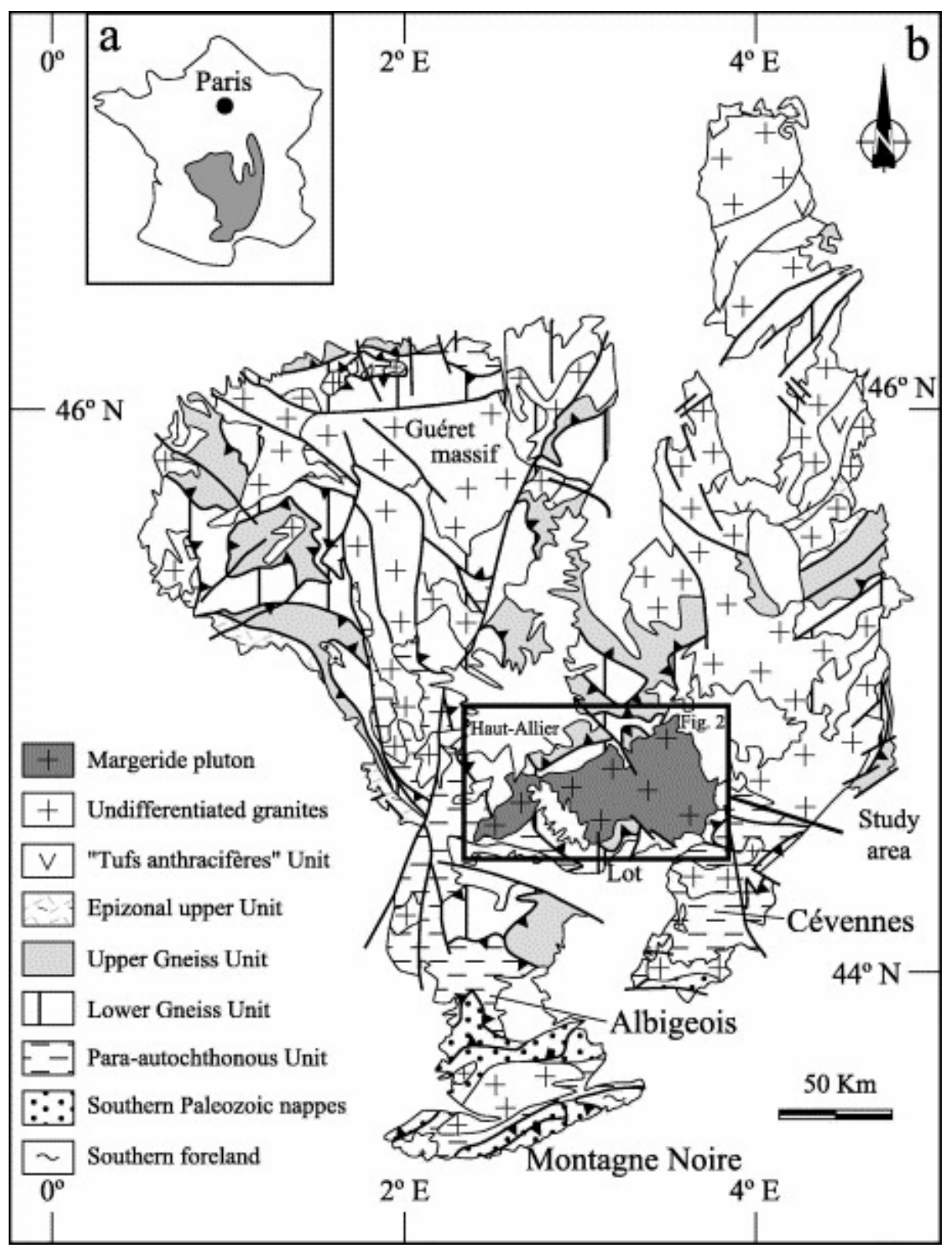

Fig. 1. (a) Location map of the French Massif Central. (b) Structural map of the French Massif Central and location of the study area. 


\section{Geologic al setting}

\subsection{General framework}

The Variscan Belt of Western Europe has long been recognised as a collisional orogen resulting from the convergence between Gondwana and Laurussia supercontinents, to the south and north, respectively (Matte, 1986). In the French Massif Central, the collision is characterised by the succession of several tectonic events between Late Silurian (ca. $410 \mathrm{Ma}$ ) and Early Permian (ca. $300 \mathrm{Ma}$ ) (e.g. Ledru et al., 1989, Ledru et al., 1994 and Faure et al., 2004). From Late Silurian to Middle Devonian, the northward continental subduction of the Gondwanian margin beneath the Armorica microplate is followed by the exhumation of high- and ultra-high pressure rocks (Lardeaux et al., 2001). A nappe stacking coeval with the exhumation of high-pressure rocks is evidenced by NE-SW-trending lineations with top-to-the-SW shearing. During Late Devonian, the occurrence of calc-alkaline magmatic rocks in the NE part of the French Massif Central is interpreted as the mark of a new subduction event and a rifting period (Faure et al., 1997). The true collision between Laurussia and Gondwana occurred in the Late Devonian-Early Carboniferous. In the northern part of the Massif Central, compression ended in the Early Carboniferous (ca. 360-350 Ma), whereas it lasted up to the Middle Carboniferous (ca. $330 \mathrm{Ma}$ ) in the southern part. This Middle Carboniferous compressional event is characterised by south-directed ductile shearing (Mattaver and Etchecopar, 1977 and Burg and Matte, 1978). The entire Massif Central experienced its first extensional event due to lateorogenic collapse during the Middle to Late Carboniferous (ca. 325-310 Ma). Extension is diachronous, beginning earlier in the north than in the south of the Massif Central. This extension was orogen-parallel with a NW-SE maximum stretching direction (Faure, 1995). A second extensional event, coeval with the formation of coal-bearing half grabens, occurred during the Late Carboniferous-Early Permian. The general direction of this extension is N-S in the Massif Central (Burg et al., 1994). 


\subsection{The central part of the French Massif Central}

The southern central part of the French Massif Central, in the Margeride area, shows several lithological and tectonic units (Fig. 1). The Palaeozoic metamorphic rocks are unconformably covered by several Mesozoic to Quaternary volcanic and sedimentary formations. The Margeride area comprises a huge granitic pluton, the Margeride massif, surrounded by several metamorphic units separated by thrust contacts marked by mylonites and top-to-the-south shearing (Fig. 2).

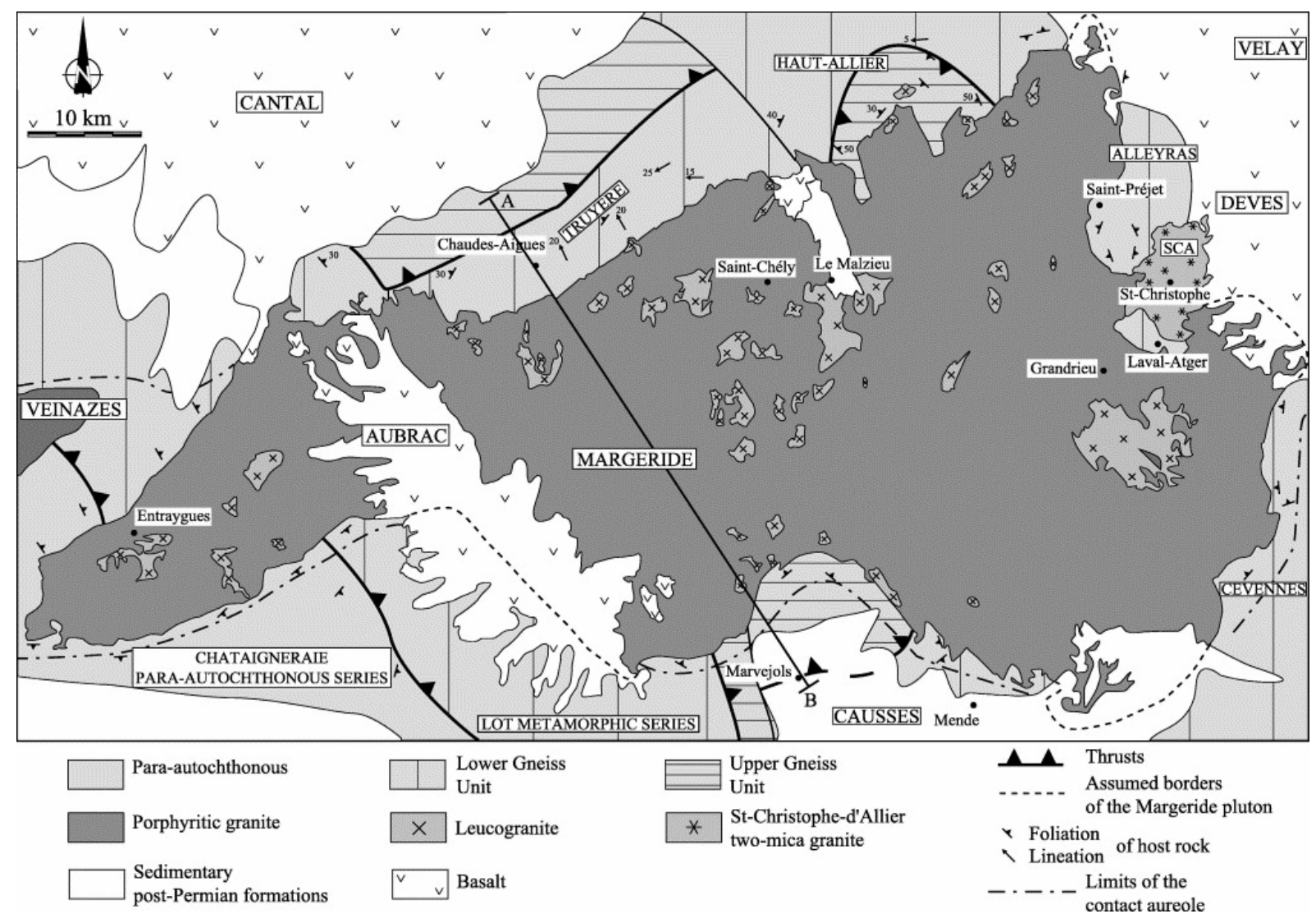

Fig. 2. Geological map of the Margeride pluton and its host rock.

These units consist of micaschists and gneisses derived from pelites, greywackes and sandstones. On the eastern border of the pluton, orthogneisses are more developed. A foliation, generally flat or slightly northward dipping, is the main structural feature of this area. This foliation and associated thrusts are related to the south-verging nappe stacking occurring 
from Late Devonian to Early Carboniferous known all over the French Massif Central. Various types of contacts, discordant, concordant or faulted, are observed between the Margeride pluton and its host rock. The width of the contact aureole varies from zero to several kilometres. Along the northern border, contact metamorphic minerals such as andalusite or biotite are frequently oriented along a N120-130 trend and are sometimes deformed (boudinaged or sheared). Shear criteria indicate normal motion, with the host rock being downfaulted with respect to the granite. In the thermal aureole of the southern margin, micaschists exhibit NW-SE mineral lineations of boudinaged contact minerals (biotite, albite and cordierite). The sigmoidal shape of the biotite and asymmetric quartz pressure shadows indicate a topto-the-NW shear. These structures, coeval with the granite emplacement, are considered as markers of the late-orogenic NW-SE extensional event (Faure, 1995). To the NE of the Margeride pluton, the uprise of the Late Carboniferous Velay granite-migmatitic dome tilted the previous structures to the west (Feybesse et al., 1995 and Ledru et al., 2001).

\section{The Margeride granitic complex}

\subsection{Petrography and geochronological data}

The Margeride massif is the largest post-Visean granitic complex in the French Massif Central. The massif, elongated in an E-W direction, covers an area of $3200 \mathrm{~km}^{2}$ and is cut into two parts by the Tertiary Aubrac volcanic plateau (Fig. 2). The westernmost part is called the Entraygues appendix. One of the peculiar features of this pluton is the numerous NW-SE-trending joints and faults. These structures are also found on the pluton borders because most of the faulted-contacts have this NW-SE trend. The Margeride granitic complex consists mainly of a porphyritic monzogranite facies, called Margeride granite sensu stric to (Fig. 3a) and to the east, the Chambon-le-Château granite, 
which compared with the monzogranitic facies shows grain size reduction and biotite enrichment (Couturié, 1977).
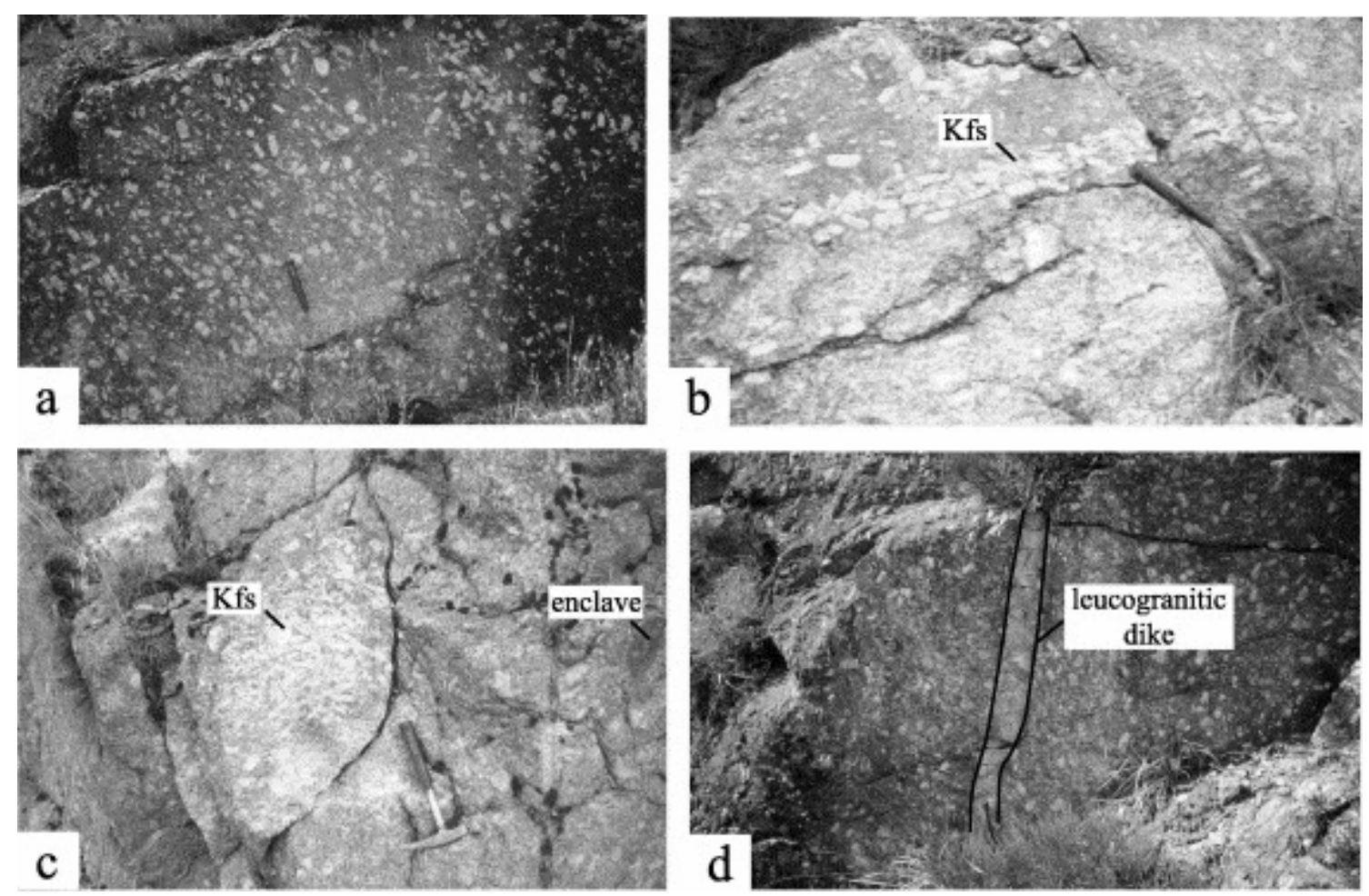

Fig. 3. Examples of outcrops of the Margeride granitic complex. (a) Typical aspect of the porphyritic granite facies (AMS sampling site M8). (b) Oriented accumulation of potassic feldspar megacrysts (AMS sampling site M137). (c) Accumulation of potassic feldspar megacrysts and mafic microgranular enclave (road D900 close the AMS sampling site M161). (d) Steep-dipping leucogranitic dike cutting the porphyritic granite facies. The dyke is about $10 \mathrm{~cm}$ wide. The contacts of the dyke are sharp, indicating a strong rheological contrast between the two granite types (AMS sampling site M8). Kfs, K-feldspar.

Due to the petrological and structural similarities between the Margeride granite sensu stricto and Chambon-le-Château granite, these two types will be described as a single one. The main facies consists of K-feldspar megacrysts enclosed in a quartz, K-feldspar, plagioclase (andesineoligoclase), biotite and locally muscovite, groundmass. K-feldspar megacrysts generally do not show any particular preferred orientation; however, locally, especially along the pluton margins, the megacrysts can be oriented (Fig. 
3b). Couturie (1977) defined three sub-facies in the Margeride porphyritic granite according to the amount of biotite, namely the 'dark', 'medium' and 'light' sub-facies. The 'dark' sub-facies is observed only in the eastern part of the Margeride pluton. Moreover, the porphyritic facies encloses some mafic enclaves with variable compositions (Fig. 3c). It is also cross-cut by numerous leucogranite bodies and dykes that trend generally NW-SE or NE-SW (Fig. 3d). The texture of leucogranites range from aplitic to pegmatitic and their composition is quartz, K-feldspar, plagioclase (oligoclase-albite), muscovite and minor biotite. Tourmaline (schorlite) grains are locally observed in some leucogranite dykes. Due to N-S-trending large-scale upright folding related to the emplacement of the Velay dome (Fig. 2), the massif floor is well observed along the eastern margin. There, the Saint-Christophe-d'Allier two-mica granite (SCA in Fig. 2) exhibits a well-marked subsolidus fabric with a NW-SE mineral and stretching lineation. This two-mica granite is composed of quartz, K-feldspar, plagioclase, biotite and muscovite; those two latter being roughly in equal contents.

The Margeride complex was emplaced at the end of the Variscan orogeny as indicated by the geochronological ages. Previous data on the Margeride porphyritic monzogranite yield older ages, namely $323 \pm 12 \mathrm{Ma}$ (Rb/Sr on whole

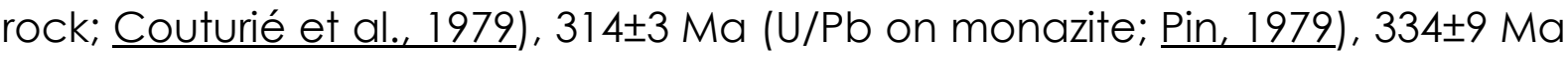
(U/Pb on zircon; Respaut, 1984). Moreover, new ${ }^{40} \mathrm{Ar} /{ }^{39} \mathrm{Ar}$ results on biotite indicate younger cooling ages at $310 \pm 3$ and $306 \pm 3.1$ Ma (Monié et al., 2000 and Ialbot, 2003). The Chambon-le-Château granite yields an age of $311 \pm 6 \mathrm{Ma}$ with $\mathrm{U} / \mathrm{Pb}$ on monazite (Isnard, 1996). Although the formation of the Margeride granitic complex as several stages cannot be totally excluded, the most recent and reliable data suggest that the emplacement of the porphyritic granite occurred around $310 \mathrm{Ma}$. Only one date of $305 \pm 14 \mathrm{Ma}$ (U/Pb on monazite) exists for the Saint-Christophe-d'Allier two-mica granite (Isnard, 1996). Regardless of the method, the geochronological ages for the cross-cutting leucogranites are more tightly grouped and range from 307 to $298 \mathrm{Ma}$ (Couturié and Caen-Vachette, 1980, Lafont and Respaut, 1988, 
Monié et al., 2000 and Ialbot, 2003). In agreement with our structural observations, the leucogranites are younger than the porphyritic granite and were emplaced in a host granite already solidified. Therefore, the emplacement of the Margeride complex took place in Late Carboniferous times and post-dates nappe emplacement.

\subsection{Field structural obsenvations}

Previous analyses of the preferred orientation of K-feldspar megacrysts show two imbricate fabrics at the pluton scale in the Margeride porphyritic granite. One trends N60-100 and is named 'longitudinal', whereas the other trends $\mathrm{N} 140-160^{\circ}$ and is 'oblique' relative to the general elongation of the pluton (Labove, 1982 and Feybesse et al., 1995). The 'oblique' fabric is the only one developed in the eastern part of the pluton, whereas the 'longitudinal' fabric is present more in the central and western parts. The two directions of $\mathrm{K}$ feldspar megacrysts preferred orientation were interpreted to reflect emplacement and crystallisation processes of the magma (Labove, 1982). According to Labove (1982), the 'medium' and 'light' sub-facies were emplaced through a feeder zone located in the eastern part of the pluton. Then the magma expanded along an E-W direction. The 'longitudinal' fabric is interpreted as reflecting this E-W-trending magma flow. The later emplacement of the 'dark' sub-facies through the same eastern feeder zone would change the initial orientation of the primary fabric into an 'oblique' direction in the eastern area of the pluton (Labove, 1982). In a more detailed study carried out in the eastern border of the Margeride pluton, the statistical analysis of K-feldspar megacrysts preferred orientation is reinterpreted in a new structural model (Feybesse et al., 1995) according to which the mylonitic contacts observed between the Margeride, Chambon-le-Château and SaintChristophe-d'Allier plutons indicate a top-to-the-southeast shearing. Both preferred orientations would be coeval and would correspond to the same strain field. The 'Iongitudinal' orientation, developed in the centre of the pluton, is associated with coaxial flow, whereas near the floor and roof 
contacts of the granites, the 'oblique' orientation develops with a noncoaxial strain related to the regional southeastward shearing (Feybesse et al., 1995). Regardless of the emplacement model and related kinematics, the previous studies consider the Margeride granite as a laccolith-like pluton (Fig. 4).

$\mathrm{NW}$

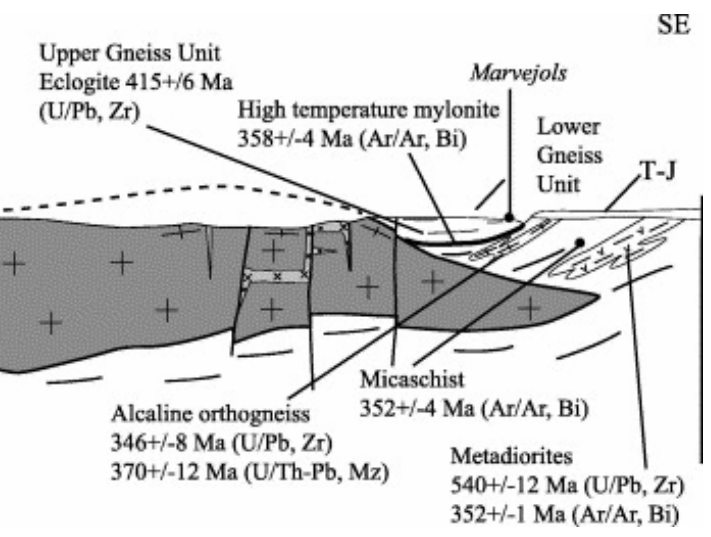

Fig. 4. NW-SE-trending cross-section of the Margeride complex (located in Fig. 2) showing the relationships between the granite and its host rock (after De Goër de Hervé et al., 1994). T, Triassic; J, Jurassic formations.

Furthermore, some local variations of the preferred orientation of K-feldspar megacrysts are observed, mainly near the northeastern border. It has been suggested that, in this area, the N-S-trending large-scale upright folding related to the emplacement of the Velay dome has reoriented the primary planar and linear structures of the Margeride complex (Couturié, 1977 and Feybesse et al., 1995).

Conversely to the porphyritic granite, very few previous structural works dealt with the leucogranite bodies in the Margeride complex. However, it is worth noting that the leucogranite dykes exhibit a peculiar orientation related to the NW-SE-trending regional extensional strain field. Leucogranite dykes trend generally NW-SE or NE-SW. The dominant NE-SW-trending dykes, perpendicular to the maximum extensional direction, might be interpreted as 
steep-dipping faults open like 'tension gashes'. Conversely, the NW-SEtrending dykes emplaced along NW-SE faults.

\subsection{Microstructures}

In the porphyritic facies, three kinds of microstructures are observed (Fig. 5). Magmatic microstructures. Many samples exhibit microstructures that are typical of magmatic flow (Fig. 5 a and b). However, some signs of a very weak solid-state overprint are sometimes present. Millimetre-sized quartz grains show weak undulose extinction and are almost free of sub-grain boundaries. A few quartz grains underwent a slight dynamic recrystallisation, as indicated by the occurrence of rare, well-individualised sub-grains. Generally, biotite grains are characterised by the lack of any evidence of solid-state deformation, such as undulose extinction or bending (Fig. 5a). Ductile deformation is completely lacking in feldspars. Compositional zonings (Fig. $5 \mathrm{~b}$ ) and syneusis of plagioclase are locally observed and K-feldspars show perthitic texture. A few late fractures indicate that a low temperature brittle deformation was recorded in these samples.

Moderate solid-state deformation microstructures. Quartz grains systematically exhibit undulose extinction, often with a chess-board texture, and evidence exists for dynamic recrystallisation, such as lobate grain boundaries (ig. $5 \mathrm{C}$ ). Large quartz grains are rarely observed since they are often replaced by numerous small recrystallised grains with irregular boundaries. Biotite is more frequently 'kinked' than in the first type of microstructures and some grains are elongated (Fig. 5c). K-feldspar displays features of intracrystalline deformation, such as undulose extinction. Some myrmekites are also observed. All these criteria are typical of a solid-state deformation (e.g. Paterson et al., 1989 and Vernon, 2000).

Significant solid-state deformation microstructures. All the primary quartz grains, without exception, are recrystallised and replaced by aggregates of newly formed grains, elongated along the same direction (Fig. 5 d). 

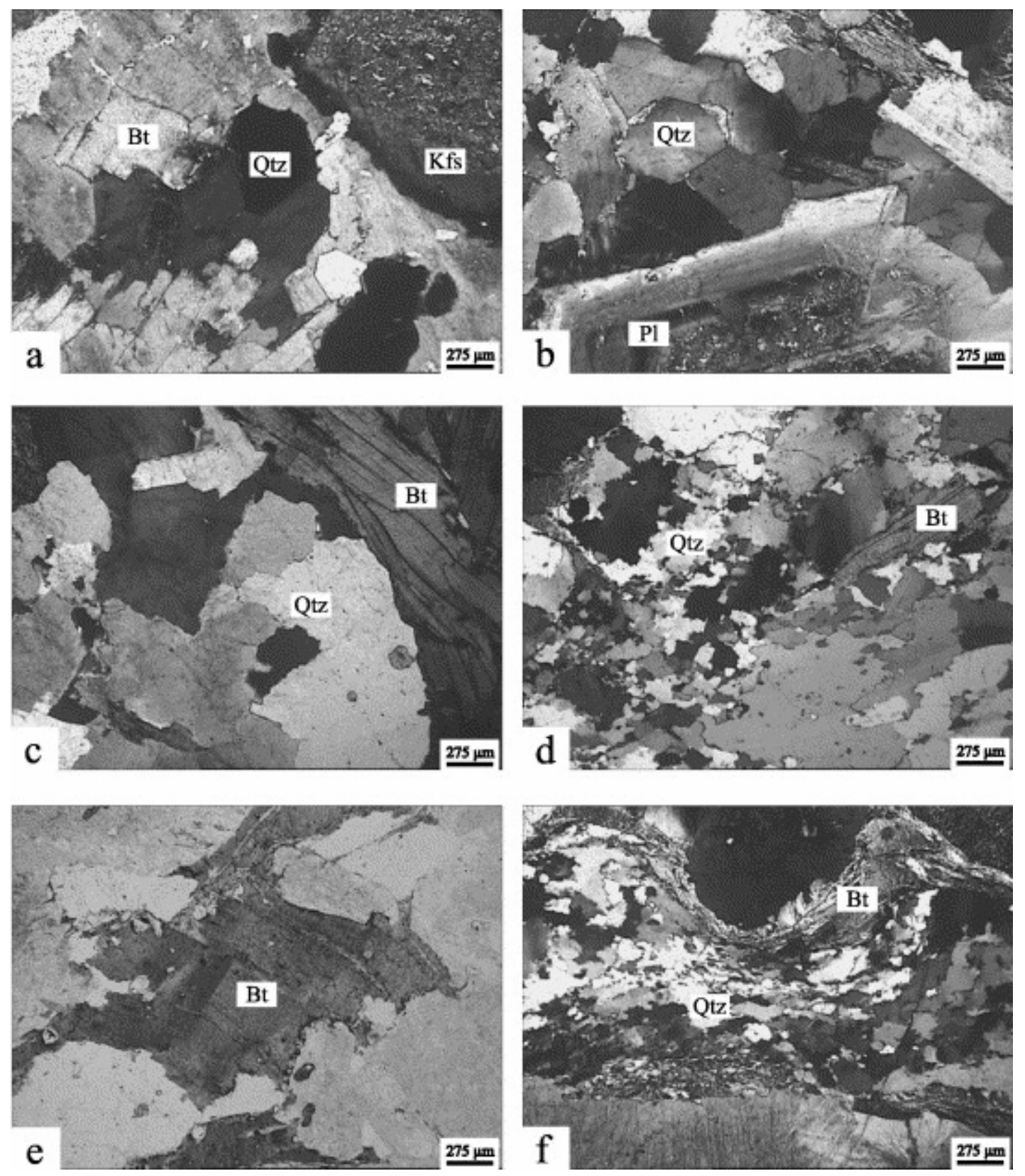

Fig. 5. Microstructures of the porphyritic granite. (a) and (b) Magmatic microstructures showing quartz grains without undulose extinction and undeformed biotites (near to the AMS sampling site M161 for (a) and AMS sampling site M18 for (b)). (c) Microstructures of moderate solid-state deformation. Quartz grains are weakly recrystallised with a slight neograin formation. Biotite is bent (AMS sampling site M02). (d)-(f) Microstructures of significant solid-state deformation. (d) Intensively recrystallised quartz grains with grain size reduction (AMS sampling site M08). (e) Biotite with significant undulose extinction (AMS sampling site M48). (f) Biotite and quartz grains with intense dynamic recrystallisation (AMS sampling site M126). Qtz, Quartz; Kfs, K-feldspar; Pl, Plagioclase; Bt, Biotite. 
Biotites are intensely deformed (Fig. 5e) and may sometimes be compared with 'mica-fish'. Locally, biotite and quartz grains are organised in ribbons forming a gneissic-like microstructure (Fig. $5 \mathrm{f}$ ). Feldspar often displays intense undulose extinction.

At the pluton scale, the distribution of these different types of microstructures shows a well-defined spatial organisation (Fig. 6). The magmatic microstructures are observed mostly in the central and western part of the Margeride granite. On the contrary, in the eastern border, most samples show a solid-state deformation and this is the only part of the massif where significant solid-state deformation microstructures occur. In the leucogranites, microstructures range from magmatic to moderate solid-state deformation, but no geographic distribution can be determined at the scale of the massif. Conversely, in the Saint-Christophe-d'Allier two-mica granite, moderate to intense solid-state deformation microstructures are observed throughout this pluton.

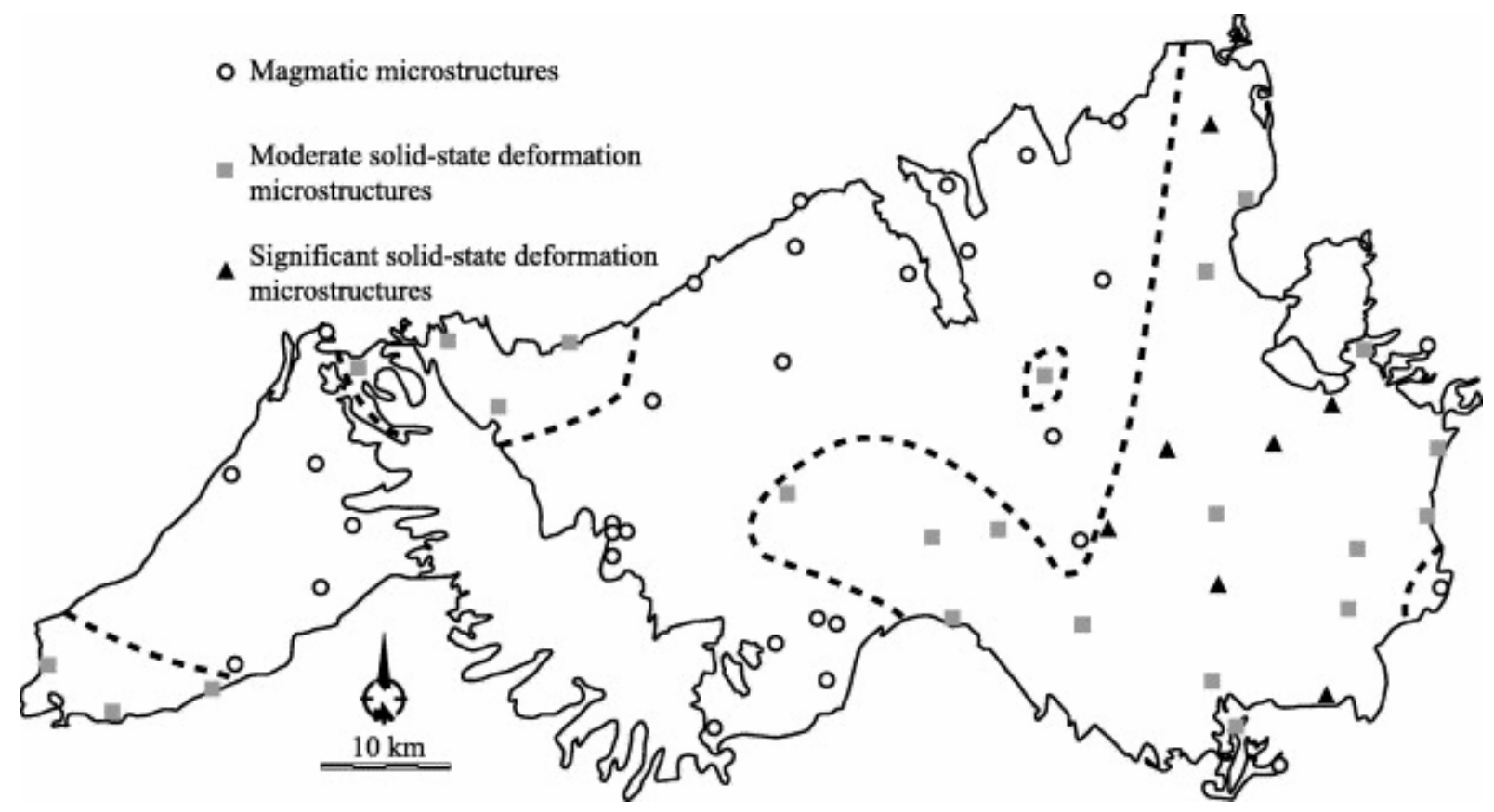

Fig. 6. Distribution of the different types of microstructures of the porphyritic facies of the Margeride pluton. 


\section{Anisotropy of magnetic susceptibility (AMS) of the Margenide granitic complex}

\subsection{Magnetic mineralogy}

The identification of the phases that contribute to the magnetic signal and its anisotropy is important in every AMS survey, because the occurrence of some minerals may lead to anomalous magnetic fabrics that cannot be easily related to kinematics (Hrouda, 1982, Tarling and Hrouda, 1993 and Borradaille and Henry, 1997). These anomalous magnetic fabrics can result from the crystallisation of new minerals after fabric formation, from the alteration of primary crystals, or due to anomalous intrinsic anisotropies of some minerals, such as tourmaline or single-domain magnetite, whose magnetic fabric orientations do not correspond to crystallographic or shape preferred orientations. Furthermore, as mentioned by Borradaille and Werner, 1994 and Borradaille and Henry, 1997, some phases, so-called ferromagnetic sensu lato, such as magnetite or hematite, even in small amounts, can strongly influence the orientation and shape of the ellipsoid of the magnetic susceptibility. In order to identify the main 'carriers' of the magnetic fabrics, several methods have been used.

The magnetic mineralogy survey was essentially carried out on the porphyritic facies. Observations have been realised with a petrographic microscope and also with a scanning electronic microscope (SEM). Biotite is the main Febearing silicate phase observed, but, locally, Fe-bearing muscovite is also present. Biotite is sometimes altered to chlorite. Because some opaque minerals are also observed in many samples, their determination has been made with SEM observations in a few samples. The main accessory phases observed were pyrite and hematite. This latter phase is generally associated with biotite crystals. The primary or secondary character of hematite has not been established. SEM observations also show the presence of rutile and tourmaline inclusions in some biotites. 
Thermomagnetic experiments show different types of magnetic susceptibility vs. temperature curves. In half of the samples, heating curves display a progressive decrease of magnetic susceptibility with increasing temperatures showing that only paramagnetic phases, such as biotite or muscovite, are present (Fig. 7a). However, the other samples reveal a decrease of susceptibility in general around $570^{\circ} \mathrm{C}$, indicating the occurrence of magnetite. Nevertheless, this decrease follows, in general, an increase of susceptibility that begins around $500^{\circ} \mathrm{C}$ (Fig. 7a). This may suggest that magnetite could be formed during the heating by a mineralogical transformation, perhaps from pyrite, but in some samples, magnetite is undoubtedly primary. Other sharp decreases, sometimes observed for 200 and $630^{\circ} \mathrm{C}$, suggest that pyrrhotite and hematite are locally present. Furthermore, cooling curves indicate that mineralogical transformations at high temperature can sometimes produce some hematite and magnetite crystals (Fig. 7a). On the contrary, the relation between the applied magnetic field and the induced magnetic moment of a sample (hysteresis loops) shows similar behaviour for most samples. Magnetic moment is linear for both increasing and decreasing magnetic fields. This complies with a predominance of paramagnetic Fe-bearing silicate phases (Fig. 7b). This last point is also evidenced by the low values of the magnetic susceptibility, $\mathrm{Km}$ (Table 1 in the supplementary data in the online version of this article). For the porphyritic granite, $\mathrm{Km}$ ranges from 33.3 to $461.3 \mu \mathrm{SI}$ with an average of $123.9 \mu \mathrm{SI}$. Such values are typical of granite whose magnetic signal mainly comes from a paramagnetic source. Based on these data, we can conclude that in the porphyritic granite, the magnetic fabric is most likely controlled by a combined contribution of biotite \pm muscovite \pm hematite \pm pyrite \pm traces of magnetite. In spite of local alteration and probable formation of minor new phases, the AMS fabric corresponds mostly to the rock primary fabric. In the porphyritic facies, anomalous fabrics are rare, and, furthermore, due to its high content relative to other magnetic carriers, biotite is the most important contributor to the AMS. 

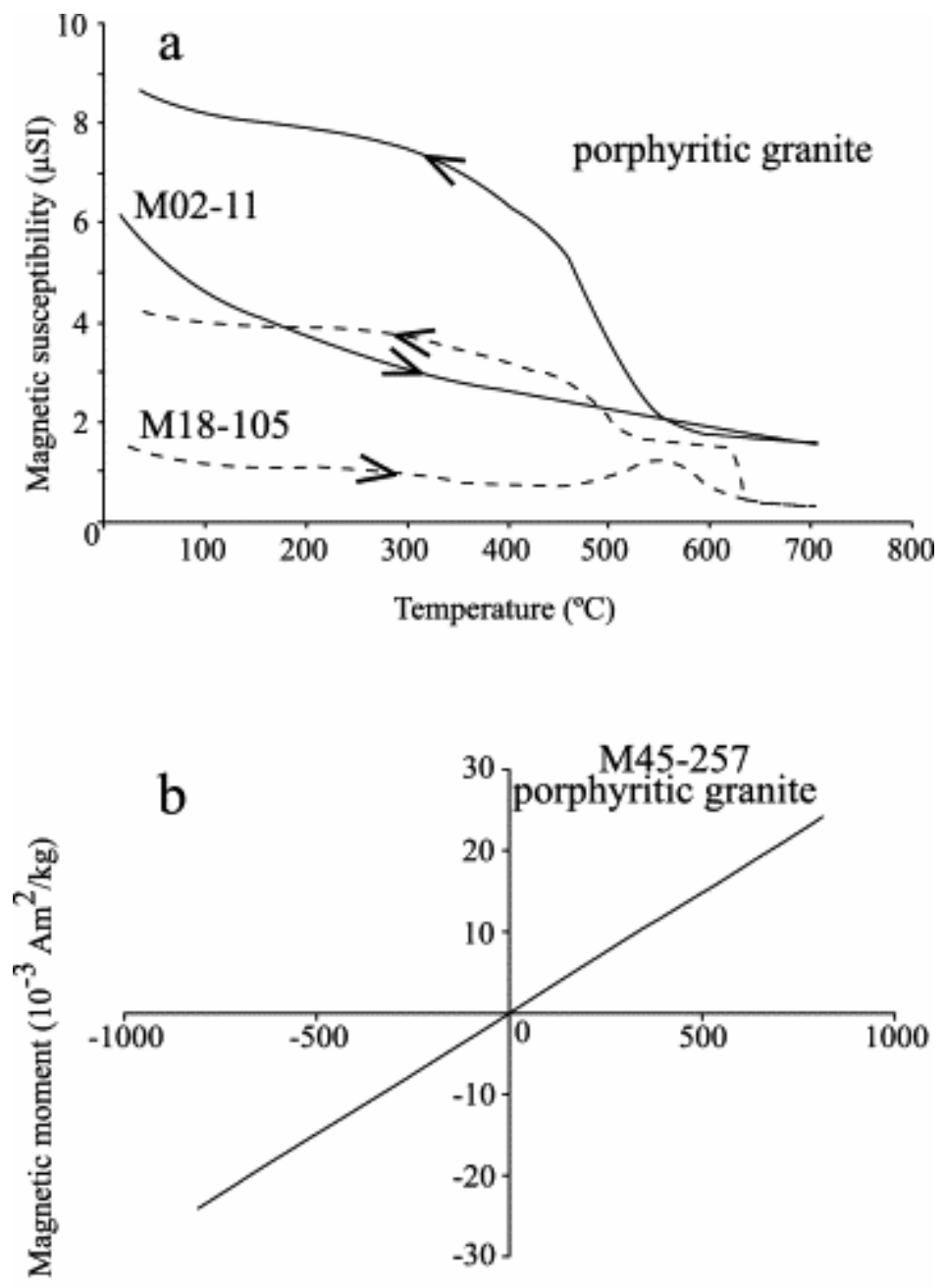

Applied magnetic field (mT)

Fig. 7. Magnetic mineralogy experiments. (a) Thermomagnetism heating and cooling curves of two samples of porphyritic granite, M02-11 (full line) and M18-105 (dashed line). In these two examples, sharp modifications of magnetic susceptibilities are mainly interpreted as due to mineralogical transformations during the experiments and not to a primary feature of our samples. (b) Hysteresis measurement of one sample of porphyritic granite, M45-257, showing the linear relationship between the applied magnetic field and the magnetic moment suggesting the predominance of the paramagnetic component.

The magnetic mineralogy for the Saint-Christophe-d'Allier two-mica granite is roughly the same as the porphyritic granite. However, since this granite contains more Fe-bearing muscovite, the contribution of this latter phase is more significant. On the contrary, the magnetic mineralogy of leucogranites 
is more complex since the biotite content may strongly vary from one sample to another. Fe-bearing muscovite is always the most abundant Fe-bearing silicate phase. As for the porphyritic facies, traces of hematite and magnetite are encountered. Locally, occurrence of tourmaline leads to the development of an anomalous fabric since tourmaline has an inverse magnetic fabric. The long axis of tourmaline crystals corresponds to the minimum axis of magnetic susceptibility ellipsoid. In tourmaline-rich samples, AMS is a mix between a normal fabric due to muscovite, hematite, etc. and an inverse fabric due to tourmaline. Thus, the fabric of such a sample will be more or less 'anomalous' according to the relative abundance of the different phases.

\subsection{Fabric results}

The magnetic fabrics were mapped throughout the Margeride pluton and for all the facies. However, this study concerns more particularly the porphyritic facies since this is the most represented one in the pluton. Furthermore, the eastern part of the massif was more explored due to better outcrop conditions. For the porphyritic facies, AMS was measured in 213 sampling sites by following the classical sampling and measurement methods described in Iarling and Hrouda (1993). The data processing was carried out according to the statistics described in Jelinek, 1978 and Jelinek, 1981. The results are given in Table 1 in the online version of this article.

In the porphyritic facies, the magnetic lineation pattern is quite well organised (Fig. 8). Magnetic lineations generally trend $\mathrm{N} 120-160^{\circ}$ with a shallow plunge $\left(<30^{\circ}\right)$ (Fig. 9a). This trend is particularly clear in the SE part of the pluton, but is also present in the central and western parts. In these latter areas, the lineation pattern is more scattered both in trend and plunge. For example, in the western part, two lineation trends are observed, namely NW-SE and E-W. 


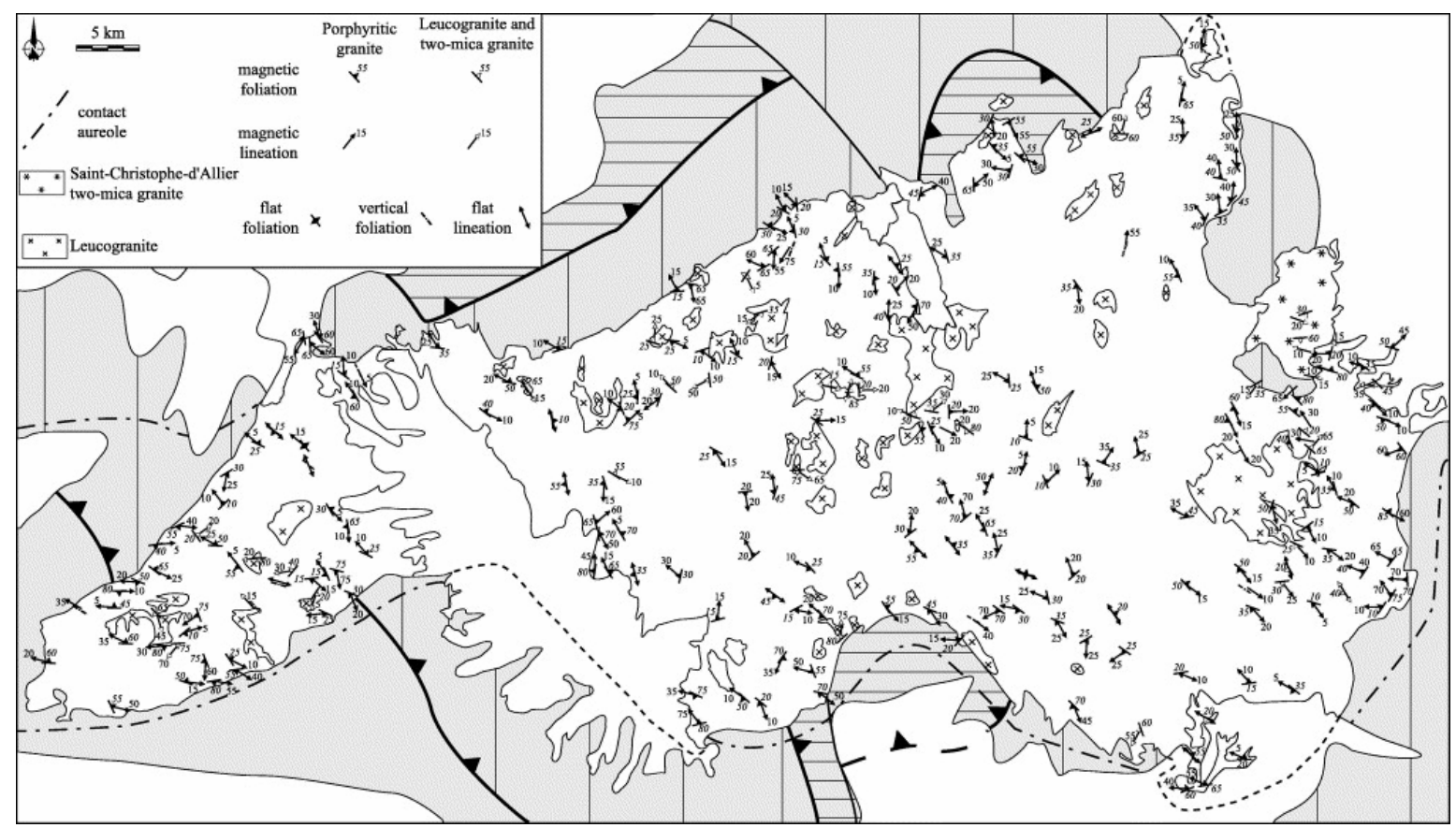

Fig. 8. Magnetic lineation and foliation of the Margeride granitic complex. Due to the high density of measurements on the eastern part, the data are not totally reported in this figure. See Fig. 2 for a more detailed figure caption.

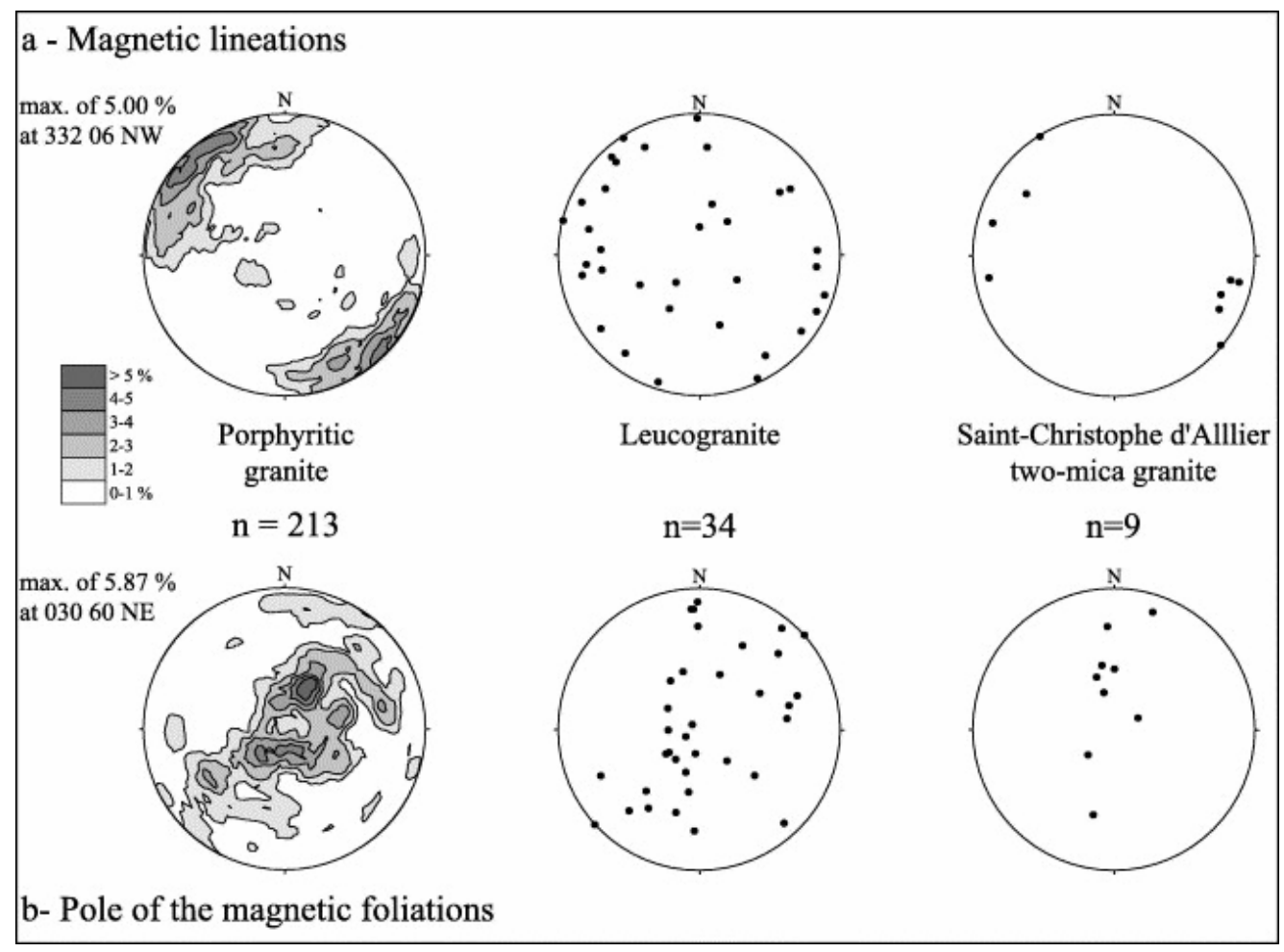

Fig. 9. Equal area projections (lower hemisphere) of the magnetic fabrics from the porphyritic granite, leucogranite and Saint-Christophe d'Allier two-mica granite. 
The NE area, around the Saint-Christophe-d'Allier two-mica granite, also presents a complex structure. Indeed, the AMS lineation forms an arcuate pattern with a change from $\mathrm{N}-\mathrm{S}$ in the north to $\mathrm{E}-\mathrm{W}$ in the south. In the SaintChristophe-d'Allier two-mica granite, the lineation pattern is subparallel with that of the porphyritic granite host. Lineations trend NW-SE in the southern part of the Saint-Christophe-d'Allier granite, whereas they trend E-W in the central part (ig. 8). The plunges are always shallow ranging from 0 to $25^{\circ}$ (Fig. 9a).

The analysis of magnetic lineation results from leucogranites shows a great scattering. However, NW-SE and NE-SW are the two dominant directions (Fig. 9a). Only to the southeast of the Saint-Christophe-d'Allier granite, lineations of leucogranites present a constant E-W trend. However, at the pluton scale, no preferred orientation can be clearly established for the leucogranite facies. This can be the result of several processes. In some leucogranite samples, the potential carriers of the AMS signal (muscovite, traces of ferromagnetic minerals) are so rare that the AMS measurement may either be influenced by diamagnetic phases such as quartz and feldspars or may not be representative of a petrofabric from a statistical point of view. Furthermore, as stated above, in samples where tourmaline is present, an anomalous AMS fabric develops.

The main feature of the magnetic foliation, in the porphyritic facies, is its conspicuous subhorizontal dip (Fig. 8 and Fig. 9). This flat attitude is the cause for the scattering of foliation strike. Near the pluton borders, the foliation is often parallel to the contact with host rock, but dips are variable, either inward or outward of the pluton. Nevertheless, it is worth noting that sometimes the foliation is oblique to the pluton borders. In the inner part of the massif, the foliation trends are more variable although, in some areas, foliations regularly strike NW-SE with a SW- or NE-ward dip.

In the Saint-Christophe-d'Allier two-mica granite, only foliations located in the central part of the pluton show a clear pattern (Fig. 8). There, foliations strike 
E-W with a moderate to strong southward dip. In the leucogranites, the magnetic foliations do not have a clear attitude. For example, dips are highly variable (Fig. 9b).

To summarise, the main structural feature of the Margeride pluton inferred from our AMS analysis is clearly the conspicuous NW-SE trend and subhorizontal attitude of the magnetic lineation (Fig. 9a). Such a pattern complies with those already described in other plutons of the Cévennes area (Talbot, 2003 and Talbot et al., 2004).

\section{Gravity study}

The Margeride granitic complex has already been the topic of several gravity studies (Aghshahi, 1979, Pétrequin, 1979 and Van de Meulebrouck, 1983). From the 1:1,000,000 gravity map of France, Aghshahi (1979) observed that the Margeride pluton corresponds to a large negative gravity anomaly and proposed a laccolithic-like shape for it. A more detailed analysis carried out by Pétrequin (1979) with numerous measurements in the western and central parts of the pluton led this author to assume an emplacement of the prophyritic granite through three NE-SW-trending feeding zones, deduced from the first vertical derivative of the anomaly and located in western, central and eastern parts of the pluton. Aghshahi, 1979 and Pétrequin, 1979 have also modelled some 2D cross-sections along the southern border of the pluton, oriented in the $\mathrm{N}-\mathrm{S}$-direction only. The eastern border was less explored and the deep structural relationships between the porphyritic granite and the Saint-Christophe-d'Allier two-mica granite are still unknown. Furthermore, none of the previous studies have built E-W-trending models in order to visualise the shape of the pluton along its largest dimension, crosscutting the possible feeder zones proposed by Pétrequin (1979). Therefore, 520 new gravity stations have been surveyed along the eastern border of the pluton to complete the existing gravity data (Fig. 10a). 

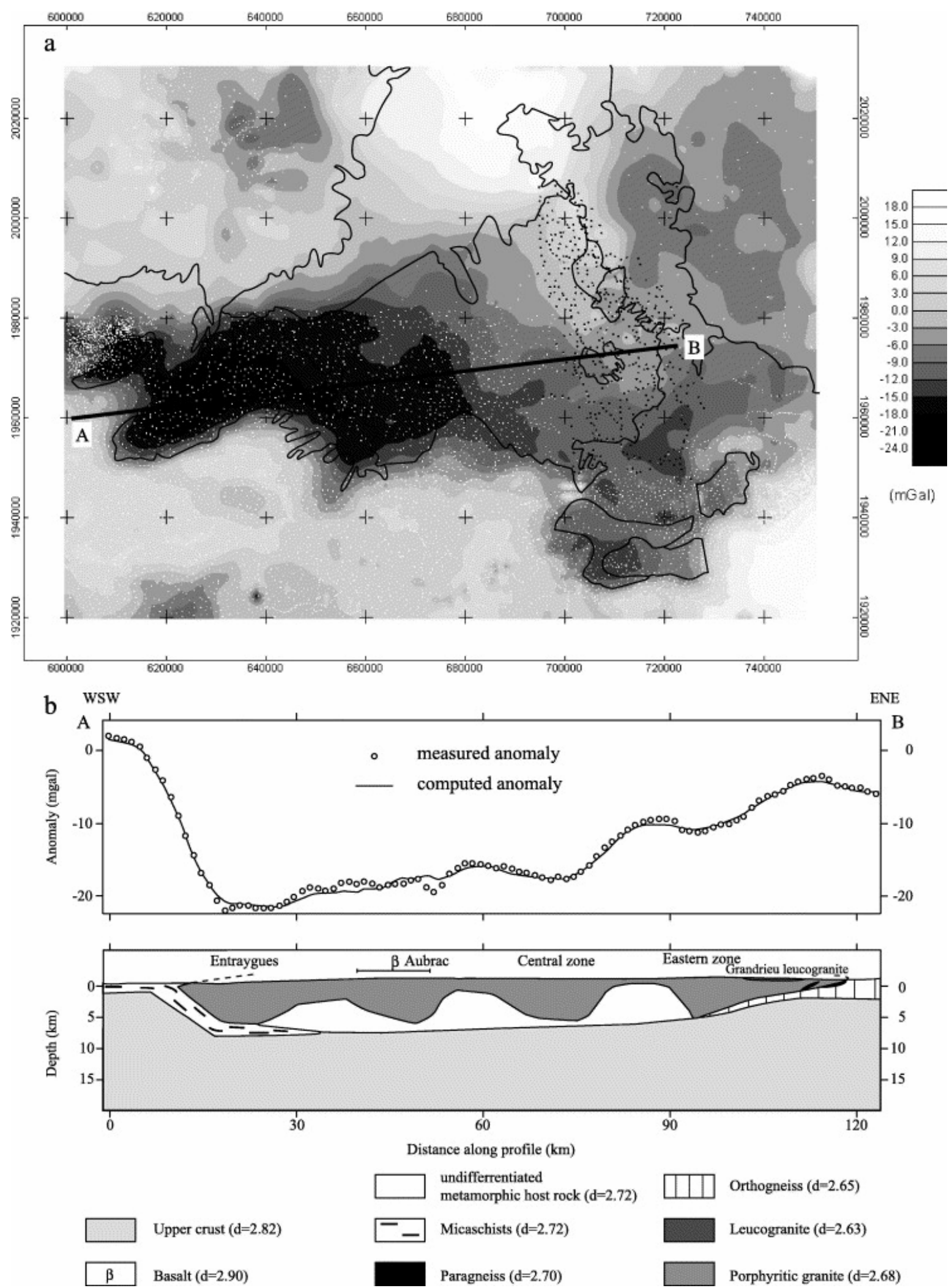

Fig. 10. (a) Map of the residual Bouguer anomaly with location of previous (white dots) and new (black dots) gravity stations. Major geological limits (thin black lines) and location of the gravity profile (thick black line) are drawn. (b) Direct 2D modelling along a WSW-ENE crosssection. The model is based on the surface geology and the constraints obtained prior to modelling. 
The resulting gravity coverage allowed us to improve the gravity anomaly all over the pluton and to build up gravity models. Joint interpretation of the gravity map and cross-sections gives insights into the 3D shape of the pluton, which is a prerequisite to propose an emplacement model.

\subsection{Residual Bougueranomaly}

Previous and new gravity data have been tied to the Carte Gravimétrique de la France 1965 (CGF65) gravity reference network and reduced to the Hayford 1930 ellipsoid. Usual free air and plateau corrections have been made. A Bouguer reduction density of $2.60 \mathrm{~g} / \mathrm{cm}^{3}$, close to the granite density, was used. The terrain corrections were computed out to $167 \mathrm{~km}$ in order to obtain the complete Bouguer anomaly. Therefore, a good integration of the new dataset within the French gravity database is achieved. In order to highlight the granite related anomalies, the long wavelengths of the complete Bouguer anomaly were removed from the signal. This was achieved using a low-pass filter of Gaussian-type with a cutoff wavelength of $250 \mathrm{~km}$ over the entire Massif Central. The resulting residual Bouguer anomaly represents the effect of density heterogeneities located below the topography, down to a few kilometres (Fig. 10a). To the first order, negative anomalies can be correlated to the granitic pluton. To the south, the pluton-host rock boundary generally coincides with a strong gradient that suggests a steep contact between the two units (Aghshahi, 1979 and Pétrequin, 1979). On the contrary, to the north, despite the very weak measurement coverage on this border, the negative anomaly extends over the metamorphic units, suggesting that the pluton plunges gently below the host rock (Aghshahi, 1979 and Van de Meulebrouck, 1983). The negative anomaly is in continuity with the other negative anomalies observed to the west and to the SE, upon the Veinazès and the Mont-Lozère plutons, respectively (Talbot et al., 2004). However, more detailed gravity studies and structural constraints in the host rocks preclude any link at depth between 
those plutons (Faure, 1995, Faure et al., 1999, Faure et al., 2001 and Olivier and Améglio, 2002). The eastern border displays the highest gravity values that suggest a thinning of the granite eastward. More negative anomalies on the rest of the pluton correspond to thicker parts or lower density facies. The most negative values are observed in the west of the pluton, but the central part of the pluton and the Aubrac area (dense basalts) exhibit very negative anomalies as well. This latter anomaly is surprising: in our modelling, we assumed a large amount of granite beneath the Aubrac volcanics in order to balance the high density of basalts. However, this solution is certainly not the only way to explain the anomaly and would certainly require more detailed study.

\subsection{Constraints prior to modelling}

To build 2D models, some constraints, such as pluton structure and densities of lithological units, are needed. Geological information, such as geological contacts and structural data, are the main constraints that can be used in the Margeride area. This information is deduced from geological maps and field observations. For example, in host rock, several lithological units have been distinguished: micaschists, paragneisses and orthogneisses. Densities of these units were taken from previous studies (Pétrequin, 1979) and new measurements (Talbot, 2003). General density values, particularly for the basalts, were extracted from the literature. Previous and new density measurements are in good agreement and are also concordant with those known for other similar plutons around the study area (Martelet et al., 1999). The density values used in our model are given in the lower part of Fig. 10b. Furthermore, one $\mathrm{E}-\mathrm{W}$-trending seismic profile crossing the central part of the pluton yields a maximum thickness ranging from 7.5 to $8.85 \mathrm{~km}$ in this area (Bayer et al., 1982). 


\subsection{D modelling}

In order to image the deep structure of the Margeride pluton, the residual gravity anomaly has been modelled along a WSW-ENE-trending profile across the whole pluton (see location on Fig. 10a). Although not strictly perpendicular to the major gravity anomalies, this profile has been chosen in order to provide an overall image of the pluton at depth. Other more detailed gravity models located on the eastern border of the pluton can be found in Talbot (2003). As seen below, because the nature (and therefore the density) of the host rocks vary around the Margeride batholith, we thought that performing directly the 3D inversion of the gravity anomaly in terms of an interface between the granite and its basement would not have been correct. Rather, we preferred a 2D direct modelling approach, which would let us better explain the assumptions of the model.

The western host rock consists of micaschists, whereas the eastern one is dominated by orthogneisses (Fig. 10b). As indicated by the geological maps, some paragneissic lenses are located between the pluton and the host rock orthogneisses, but also into the granitic pluton. In the central part of our model, where the real petrological nature of the host rock is unknown, micaschist is the most likely lithology and consequently a density of $2.72 \mathrm{~g} / \mathrm{cm}^{3}$ was assumed for a so-called 'undifferentiated host rock' metamorphic unit. The profile cross-cuts several thin units, the Aubrac basaltic plateau and the Grandrieu leucogranite massif. Their influence is almost negligible due to their minor thickness. The thickness of these units was determined using the geological maps and field observations. For the Aubrac basalts, a maximum thickness of $200 \mathrm{~m}$, consistent with the geological map (De Goër de Hervé et al., 1994), was used.

The main feature of the model is the variation in thickness of the porphyritic granite (Fig. 10b). Four zones are characterised by a thickness of 5-7 km of granite and are located (i) on the western border, (ii) beneath the Aubrac basalts, (iii) in the central part, and, finally, (iv) to the east of the pluton. 
Between these areas, the granite is thinner, ranging between several hundred metres and $3 \mathrm{~km}$. The progressive thinning observed on the eastern border complies with the decrease of the gravity anomaly.

Three of the thickened zones, namely in the Entraygues appendix, the central and the eastern parts, correspond to the NE-SW-trending minimum gravity axes identified by Pétrequin (1979). On the residual gravity anomaly map (Fig. 10a), the negative gravity anomalies corresponding to these thickened zones trend also NE-SW. Conversely, the fourth thickened zone, beneath the Aubrac basalts, complies with a negative anomaly trending NW-SE.

\section{Disc ussion}

\subsection{Interpretation of the gravity results and shape of the pluton}

From the geological contacts, the gravity map and modelling, it is possible to establish the likely overall 3D shape of the pluton in order to build a reliable emplacement model. The Margeride complex presents some peculiar features on the geological map. Indeed, the eastern part is much larger ( $~$ $55 \mathrm{~km}$ ) than the Entraygues appendix $(\sim 15 \mathrm{~km})$, resulting in a rough triangular shape of the massif. Furthermore, the southern margin exhibits a peculiar shape with two important offsets (Fig. 2). The western one separates the Entraygues appendix from the central part, presently it corresponds to the Aubrac plateau. The second one, to the north of Mende, separates the central and eastern parts of the pluton. It is worth noting that these two offsets are in the same sense.

The WSW-ENE-trending gravity profile allows us to identify four deepening zones of the pluton (Fig. 11). Three of them, trending NE-SW, are located in the centre of each of the three parts of the massif, that is the Entraygues appendix, the central and the eastern parts. These negative anomalies correspond to the three minimum gravity axes identified by Pétrequin (1979). The fourth negative gravity anomaly, trending NW-SE, corresponds to the 
Aubrac plateau and also to an offset zone. Such negative anomalies and deepening zones in granites are often interpreted as feeder zones (Vigneresse, 1990 and Améglio et al., 1997). Furthermore, Pétrequin (1979) have already proposed that the three NE-SW-trending negative anomalies could be three pluton feeder zones. In agreement with this interpretation, we consider that the Margeride pluton emplaced through four feeder zones, three trending NE-SW and the fourth NW-SE. From these structural and geophysical features, a 3D diagram of the Margeride pluton can be schematically sketched out (Fig. 12).

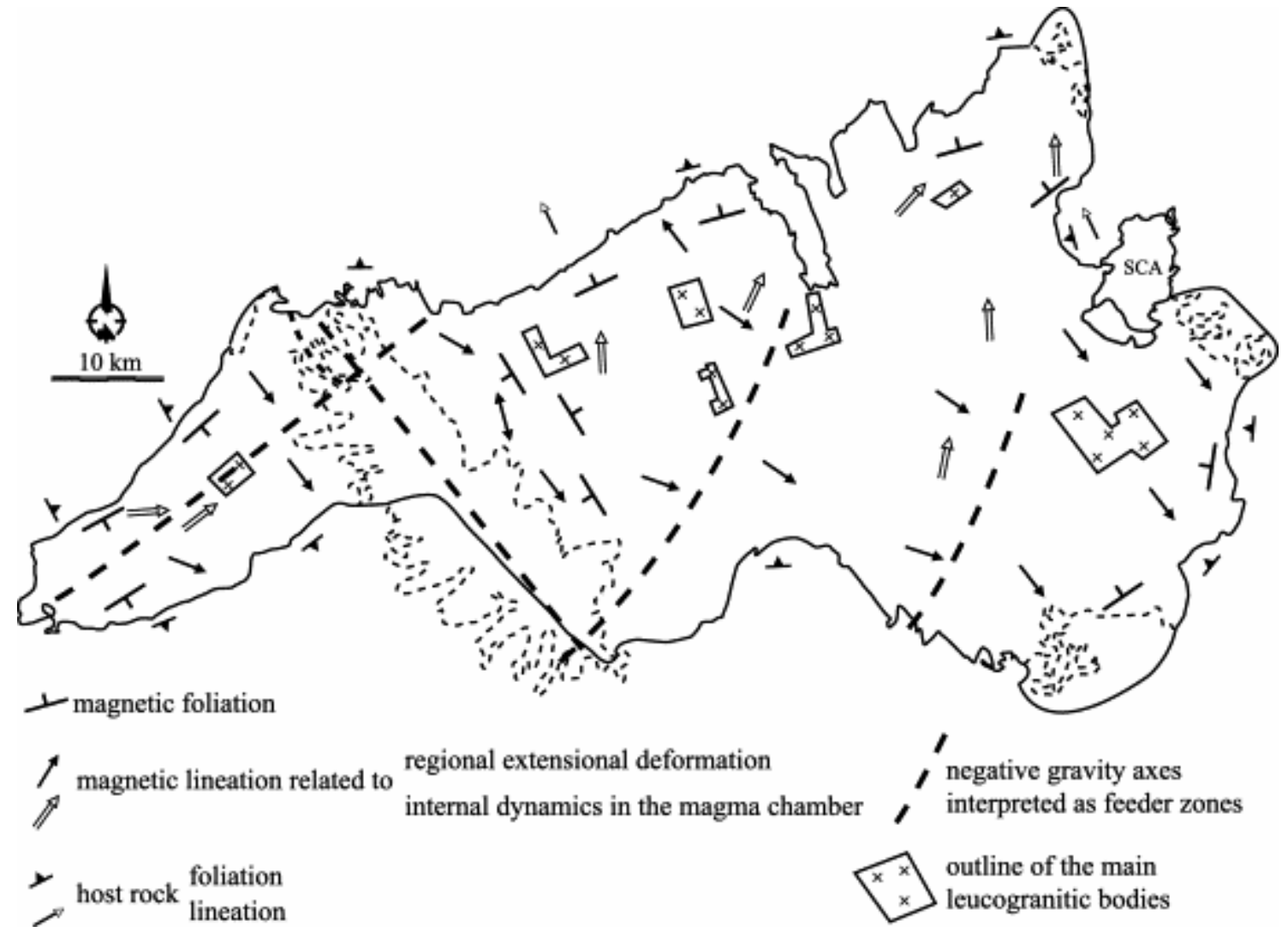

Fig. 11. Synthesis of the AMS and gravity data with location of the most negative gravity anomalies (thick dashed lines) that are considered as feeder zones of the porphyritic facies. In the pluton, the summarised pattern of the magnetic fabric of the porphyritic facies is interpreted in the regional tectonic framework. SCA, Saint-Christophe-d'Allier two-mica granite. 


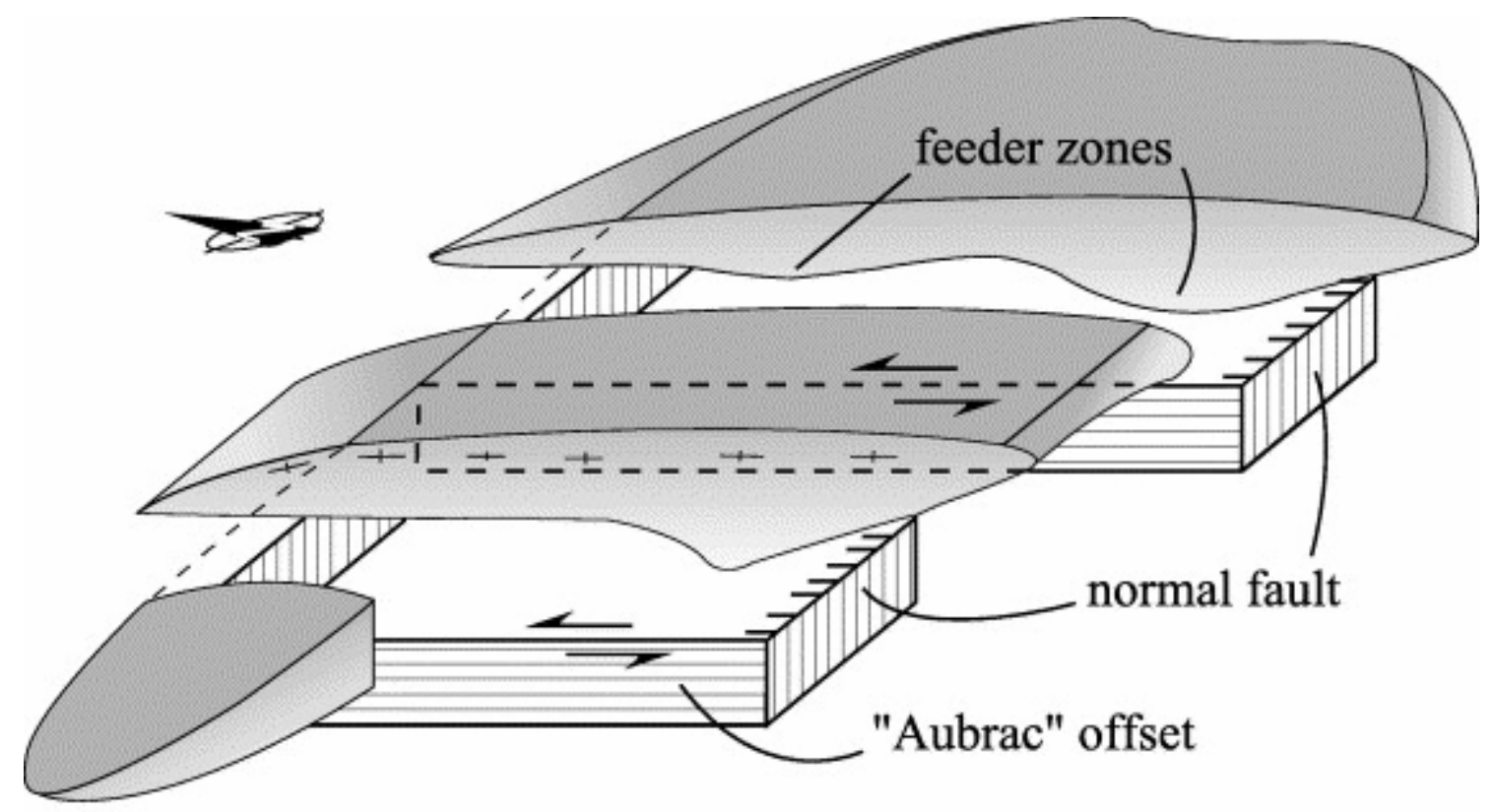

Entraygues appendix

Fig. 12. 3D diagram of the Margeride granitic complex in which the two offsets between the western, central and eastern parts of the pluton are interpreted as left-lateral faults of two pull-aparts.

\subsection{Interpretation of the magnetic fabrics in the regional tectonic framework}

The microstructures observed in the porphyritic facies are typical of magmatic-state and high temperature solid-state deformation (Paterson et al., 1989 and Vernon, 2000). This suggests that the magnetic fabric of the prophyritic facies developed during, or just after, the complete crystallisation of the magma. However, the lack of significant subsolidus deformation at the microstructural scale does not preclude that late tectonic deformation occurred. To interpret the magnetic fabrics, it is necessary to compare the internal fabrics of the plutons and the coeval host rock structures (Paterson et al., 1998, Benn et al., 1999 and Benn et al., 2001).

During the emplacement and crystallisation of the Margeride complex, in Namurian-Westphalian times, the French Massif Central experienced a general NW-SE extension that is also inferred from the internal structures of several plutons (Faure et al., 1992, Faure, 1995, Talbot et al., 2000 and Talbot 
et al., 2004) and the stretching lineation in the metamorphic aureole. This maximum stretching direction is concordant with the general trend of the magnetic lineation of the porphyritic facies of the Margeride complex, suggesting that the internal structure of the pluton recorded some increments of the regional strain (Fig. 11). The NW-SE-trending lineation is observed in areas where microstructures indicate a solid-state flow (e.g. the southeastern part of the pluton), but also in some areas where magmatic flow is dominant (e.g. the central part of the pluton). This suggests a continuum of deformation during the emplacement, the crystallisation and the cooling of the porphyritic granite. Conversely, magnetic lineations (except those near the northeastern border), which are not concordant with the regional deformation, are observed only in areas of magmatic flow (e.g. the western part of the pluton), suggesting that they are likely related to internal dynamics of the magma chamber. In the northeastern border of the pluton, the arcuate shape of the lineation is likely a consequence of late deformations associated with the emplacement of the Velay dome (Couturié, 1977 and Ledru et al., 2001). Although it is quite difficult to interpret the complex pattern of the magnetic foliation, the general low dip of the foliation throughout the pluton is, however, in agreement with an extensional deformation that is characterised by a vertical maximum shortening axis (Z-axis) of the finite strain ellipsoid.

The magnetic fabrics of leucogranites are scattered and different from one leucogranitic body to another. However, the general NW-SE direction is also represented suggesting that leucogranites probably record some increments of the regional deformation. As shown in Section 3.2, the structural and kinematic pattern of the leucogranite dykes is consistent with the extensional setting proposed for the porphyritic monzogranite. Since the leucogranites are younger than the porphyritic granite, the occurrence of NW-SE-trending lineations in both lithologies would indicate that the regional extension occurred during the emplacement and crystallisation of every facies of the Margeride complex. 


\subsection{Feeding and emplacement model}

Based on the gravity and AMS results presented above, an emplacement model can be proposed. Although a full 3D modelling has not been performed, the combination of an E-W cross-section and the gravity map gives an overall visualisation of the shape of the pluton. From east to west, it is a 1-3-km-thick laccolith-like pluton, with four 5-7-km-thick axes that are interpreted as probable feeder zones. The geometric features and the organisation of these feeder zones are integrated in the regional tectonic framework. Furthermore, the microstructures indicate that the internal fabric was acquired during, or just after, the crystallisation of the magma. Moreover, as already discussed, this fabric is mainly related to the extensional regional deformation. Consequently, the regional stretching direction is the same during the emplacement, the crystallisation and the cooling of the Margeride complex. Finally, geochronological data allow us to rebuild the history of the pluton and the successive episodes of emplacement and cooling experienced by the different facies (Monié et al., 2000 and Ialbot, 2003).

A four-stage feeding and emplacement model is proposed (Fig. 13). 


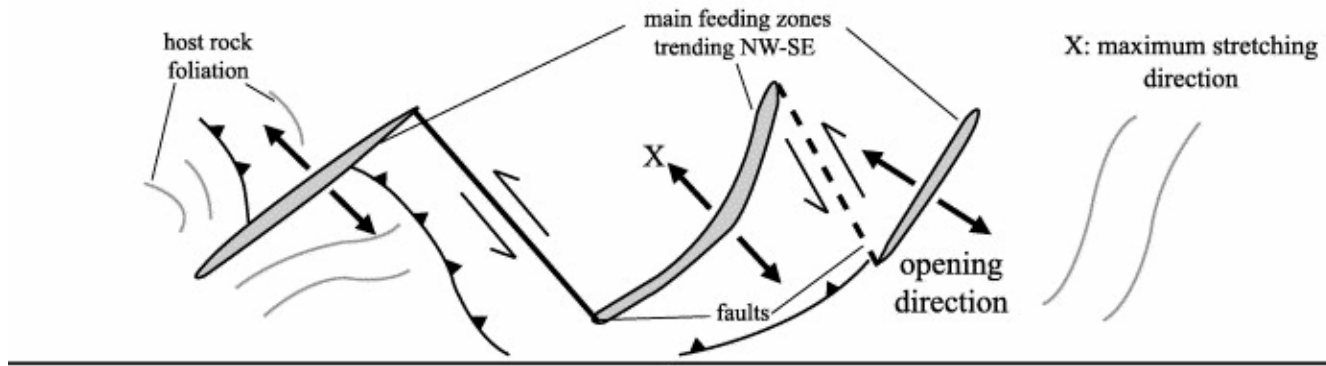

X: maximum stretching direction

$\mathrm{b}$ : Widenning of the feeder zones

ca. $310 \mathrm{Ma}$

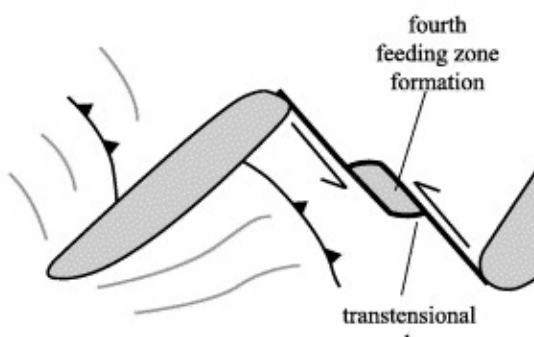

relay

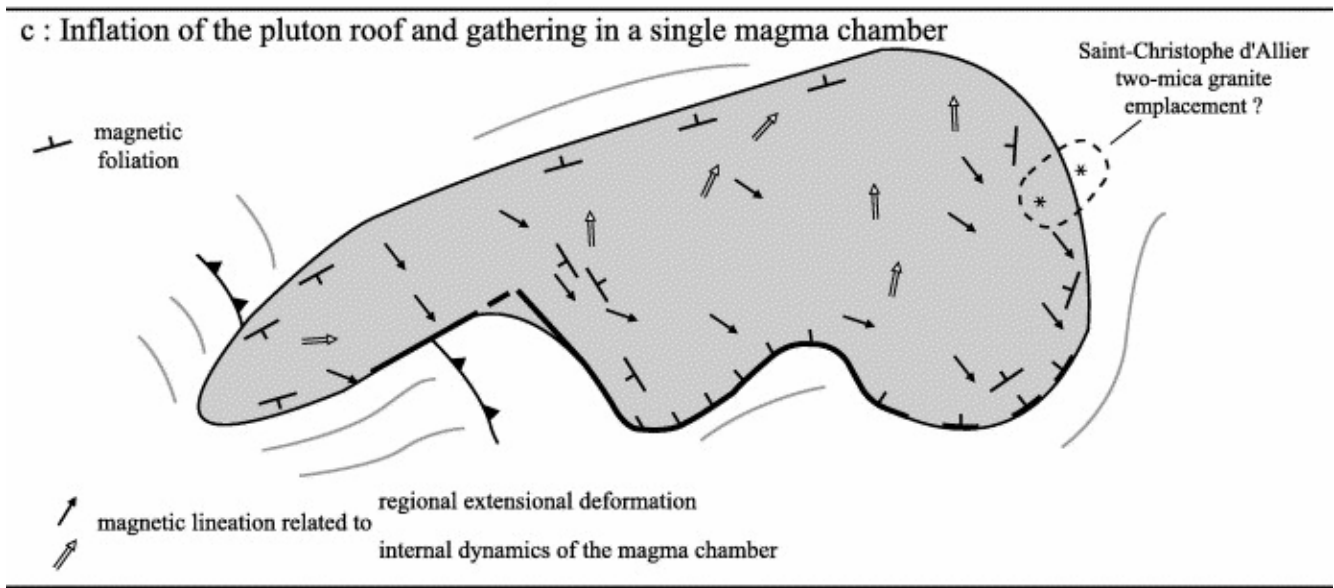

d : Emplacement of leucogranites

ca. $305-300 \mathrm{Ma}$

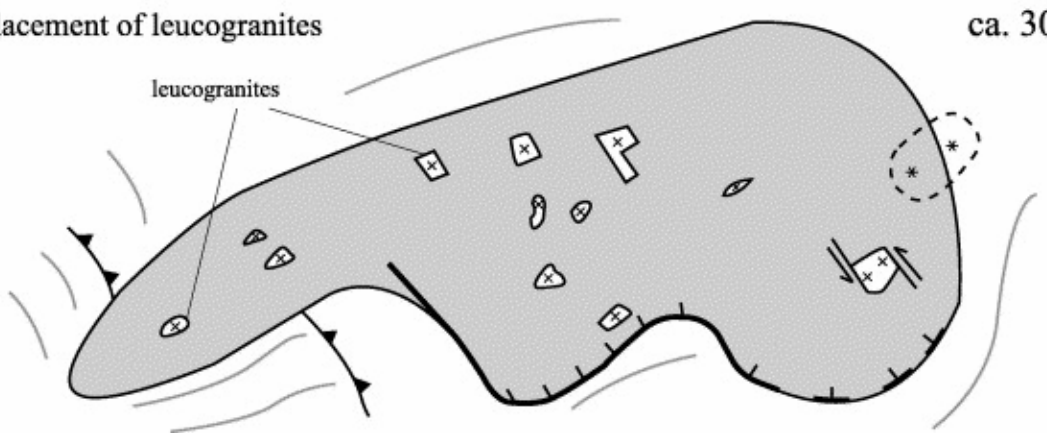

Fig. 13. Emplacement model for the Margeride granitic complex. (a) and (b) Emplacement of the porphyritic granite through four feeder zones, three of them trending NE-SW can be interpreted as extensional fractures. The last feeder zone is a sinistral transtensional jog trending NW-SE. (c) Inflation of the pluton roof and gathering of the magma in a single magma chamber. At the same time, the Saint-Christophe-d'Allier two-mica granite was emplaced. (d) Leucogranites cross-cut the porphyritic massif; their emplacement is guided by the structure of the porphyritic granite (see text for further details). 
Stages 1-2. Around $310 \mathrm{Ma}$, the magma chamber of the Margeride complex was formed by three main feeder zones trending NE-SW to NNE-SSW, which correspond to three minimum gravity axes (Fig. 13a). These zones can be interpreted as 'tension gashes' or extensional fractures perpendicular to the NW-SE maximum stretching direction. These feeder zones are linked by sinistral transfer faults trending NW-SE, which are deduced from the peculiar shape on the geological map of the Margeride pluton as described above (Fig. 12). The fourth minimum gravity anomaly, located below the current Aubrac plateau, is also interpreted as a feeder zone (Fig. 10b). In this case, the NW-SE-trending Aubrac feeder zone worked as a sinistral transtensional jog between the two other opening feeder zones of the central part and Entraygues appendix (Fig. 13b). From these four injection zones, the magma corresponding to the porphyritic granite expands laterally, mostly along the NW and SE directions as emplacement is controlled by the NW-SE regional maximum stretching. Here, the feeder zones widen and result in normal-fault bounded graben-like valleys. During this stage 2 , the inflation of the pluton roof began above each feeder zone.

Stage 3. The continuing growth of the magma chamber of the porphyritic granite resulted in a more significant inflation of the pluton roof and a lateral expansion above the different feeder zones (Fig. 13 c). The magma coming from the different feeder zones gathered in a single large magma chamber. On the eastern border of the granite complex, the Saint-Christophe-d'Allier two-mica granite emplaced below the porphyritic granite, but still controlled by the same tectonic setting. In agreement with the microstructural observations, it is likely that at this stage, during the magma crystallisation, the internal fabric of the porphyritic granite recorded some increments of the NW-SE-trending regional extensional deformation.

Stage 4. Around 300-305 Ma, after the complete crystallisation and cooling of the porphyritic granite, leucogranite stocks and dykes cross-cut this one (Fig. 
13d). The emplacement mode of the leucogranites is not really constrained by our study. However, leucogranite dykes generally trend NW-SE and NE-SW and the stocks are often limited by contacts having the same, NW-SE and NE-SW, directions suggesting that the extensional regional tectonic and the previous structure of the porphyritic granite may have influenced the emplacement of leucogranites.

The emplacement of the Velay dome around $290 \mathrm{Ma}$ is responsible for late deformations such as the westward tilting of the eastern border of the pluton. Presently, the tilting is consistent with the westward dip of the magnetic fabrics, the eastward thinning of the porphyritic granite and the exposure of the lower level of the pluton (Couturié, 1977).

This emplacement model can explain the $\mathrm{E}-\mathrm{W}$ difference in shape of the Margeride complex. The eastern and central parts likely experienced a greater NW-SE stretch during the emplacement period resulting in a larger size of these areas relative to the narrower western part. The magma supply was also more important in those larger parts. It is worth noting that throughout the late Variscan times, the eastern part of the complex shows a more important magmatic activity than the western one. Indeed, after the emplacement of the Saint-Christophe-d'Allier two-mica granite, most of the leucogranites are emplaced in this eastern part of the complex. Then, later, around $290 \mathrm{Ma}$, the Velay dome was emplaced more eastwards. This suggests a repetition of magmatic events in this area during at least $25 \mathrm{Ma}$.

Our feeding and emplacement model of the Margeride complex controlled by the late-Variscan extensional regional strain is not in agreement with previously proposed models (Couturié, 1977, Labove, 1982 and Feybesse ef al., 1995). The NW-SE-trending magnetic lineation is consistent with the N140$160^{\circ}$-trending 'oblique' fabric of the K-feldspar megacrysts, but unlike this one, the NW-SE-trending magnetic lineation is well developed throughout the pluton. Furthermore, new feeder zones are suggested by our gravity results. Indeed, the interpretation of our data is made easier by a better knowledge 
of the tectonic setting of this part of the French Massif Central during Namurian-Westphalian times and by analogy with models emphasising the compatibility of multiple feeder zones with an extensional setting (e.g. Vigneresse, 1995).

Our model is also not compatible with the emplacement model proposed for the Veinazès and Marcolès monzogranitic plutons (Olivier and Améglio, 2002) located to the NW of the Entraygues appendix (Fig. 2). These two plutons are coeval with the Margeride monzogranite. Based on gravity and AMS data, the authors propose a model implying void opening along ENE-WSW-trending sinistral wrench faults followed by a clockwise rotation of those plutons related to a NNW-SSE-trending dextral wrench. Although the 'en-échelon' geometric organisation of the feeder zones in our model could be consistent with ENEWSW-trending sinistral shear zones, this latter model fails to explain the AMS pattern in the Margeride complex. Indeed, no general 'S-shaped' AMS pattern is observed in the complex. Furthermore, a sinistral shear model would imply a steep dip of AMS foliation. On the contrary, the widespread flat-lying foliation and the NW-SE trend of the lineation throughout the Margeride pluton do not comply with such an emplacement scheme. In the regional extensional setting, local variations of the strain field can explain the peculiar emplacement mode of Veinazès and Marcolès plutons. Moreover, it is worth noting that a previous model interpreted the shape and internal fabric of the Veinazès pluton as a kind of 'tension gash' opened by a NW-SE-trending stretching, which is consistent with the regional tectonic framework (Faure, 1995).

Our model takes place in a larger scale setting taking into account the Late Carboniferous emplacement of plutons and the regional tectonics in the SE part of the French Massif Central. NW-SE-trending AMS and mineral lineations are also observed in the two other plutons of the Cévennes area namely, the Mont-Lozère-Borne and Aigoual-Saint-Guiral-Liron plutons (Talbot, 2003 and Talbot et al., 2004). The NW-SE-trending AMS lineation in the southeastern 
part of the Margeride complex is parallel to the lineation measured in the northwestern area of the Mont-Lozère-Borne complex located $10 \mathrm{~km}$ more southward. However, in the two plutons of the Cévennes area, the magnetic lineation turns $\mathrm{E}-\mathrm{W}$, parallel to the $\mathrm{E}-\mathrm{W}$-trending late-Variscan stretching and mineral lineation observed in the host rock surrounding the two plutons. It seems that a rotation of the extensional direction, from NW-SE to E-W, occurs south of the Margeride complex up to the southeastern termination of the Massif Central.

\section{Conclusions}

The AMS and microstructural study of the Margeride pluton indicates that the NW-SE-trending late-Variscan extensional regional deformation was recorded by the internal fabric of the pluton during its emplacement and crystallisation. The residual gravity anomaly and the $2 \mathrm{D}$ model reveal that the magma chamber of the Margeride porphyritic granite was fed through four zones located throughout the granite massif. The proposed emplacement model suggests that regional tectonics played a role in the emplacement mechanisms since three feeder zones are considered as NE-SW-trending extensional fractures opened perpendicularly to the maximum stretching direction, whereas the fourth feeder zone corresponds to a NW-SE-trending sinistral transtensional jog. Sinistral wrench faults act as relay or transfer faults between the NE-SW-trending feeder zones. Inflation of the pluton roof and lateral expansion are considered as main space providing mechanisms. As a whole, the emplacement model corresponds to a kind of pull-apart compatible with the general late-orogenic extensional setting of the French Massif Central. The same extensional regime also influenced the emplacement of leucogranite dykes along NE-SW-trending tension-fractures and NW-SE-striking faults. Since the early porphyritic granite and the late leucogranites emplaced during the same regional strain field, the extensional event lasted during the emplacement of every facies of the Margeride granitic complex, from the porphyritic one to the late leucogranitic one, that 
is at least $10 \mathrm{Ma}$ from 315 to $305 \mathrm{Ma}$ according to geochronological data (Monié et al., 2000 and Ialbot, 2003). This interpretation is consistent with results obtained on contemporaneous and more southern plutons in the Cévennes area (Talbot et al., 2004). This suggests that the late-orogenic extension already acted in the central and the southern parts of the French Massif Central around $315 \mathrm{Ma}$.

\section{Ac knowledgements}

This work has been partly founded by the programme 'Carte géologique de la France au 1/50000 (sheets Entraygues and St-Geniez d'Olt) directed by Philippe Rossi in Bureau de Recherches Géologiques et Minières (BRGM, French Geological Survey). Scott Paterson is thanked for fruitful discussions and constructive remarks during a field trip. Constructive revisions by Sven Morgan and Jean-Louis Vigneresse helped us to improve the manuscript.

\section{References}

Aghshahi, 1979 Aghshahi, E., 1979. Ełude gravimétrique du diapir de Qum (Iran) et du massif granitique de la Margeride (France). PhD thesis, Université de Montpellier, 115pp.

Améglio et al., 1997 L. Améglio, J.L. Vigneresse and J.L. Bouchez, Granite pluton geometry and emplacement mode inferred from combined fabric and gravity data. In: J.-L. Bouchez, D.H.W. Hutton and W.E. Stephens, Editors, Granite: From Segregation of Melt to Emplacement Fabrics, Kluwer Academic Publishers, Dordrecht (1997), pp. 199-214.

Aranguren et al., 1996 A. Aranguren, J.M. Tubia, J.L. Bouchez and J.L. Vigneresse, The Guitiriz granite, Variscan belt of northern Spain: extensioncontrolled emplacement of magma during tectonic escape, Earth and Planetary Science Letters 139 (1996), pp. 165-176. 
Bayer et al., 1982 R. Bayer, J.P. Couturié and G. Vasseur, Résultats géophysiques récents sur le granite de la Margeride, Annales de Géophysique 38 (1982), pp. 431-447.

Becker et al., 2000 J.K. Becker, S. Siegesmund and H.A. Jelsma, The Chinamora batholith, Zimbabwe: structure and emplacement-related magnetic rock fabric, Joumal of Structural Geology 22 (2000) (11/12), pp. 1837-1853.

Benn et al., 1998 K. Benn, N.M. Ham, G.S. Pignotta and W. Bleeker, Emplacement and deformation of granites during transpression-magnetic fabrics of the archean Sparow pluton, Slave Province, Canada, J oumal of Structural G eology 20 (1998) (9/10), pp. 1247-1259.

Benn et al., 1999 K. Benn, W.R. Roest, P. Rochette, N.G. Evans and G.S. Pignotta, Geophysical and structural signature of syntectonic batholith construction:the South Mountain Batholith, Meguma Terrane, Nova Scotia, Geophysic al J oumal Intemational 136 (1999), pp. 144-158.

Benn et al., 2001 K. Benn, S.R. Paterson, S.P. Lund, G.S. Pignotta and S. Kruse, Magmatic fabrics in batholiths as markers of regional strains and plate kinematics: example of the Cretaceous Mt. Stuart batholith, Physics and Chemistry of the Earth 26 (2001) (4/5), pp. 343-354.

Bolle et al., 2003 O. Bolle, H. Diot and R.I.F. Trindade, Magnetics fabric in the Holum granite (Vest-Agder, southernmost Norway): implications for the late evolution of the Sveconorwegian (Greenvillian) orogen of SW Scandinavia, Precambrian Research 121 (2003) (3/4), pp. 221-249.

Borradaille and Henry, 1997 G.J. Borradaille and B. Henry, Tectonic applications of magnetic susceptibility and its anisotropy, Earth-Sciences Review 42 (1997), pp. 49-93. 
Borradaille and Werner, 1994 G.J. Borradaille and T. Werner, Magnetic anisotropy of some phyllosilicates, Tectonophysics 235 (1994), pp. 223-248.

Bouchez, 1997 J.L. Bouchez, Granite is never isotropic: an introduction to AMS studies of granitic rocks. In: J.-L. Bouchez, D.H.W. Hutton and W.E. Stephens, Editors, Granite: From Segregation of Melt to Emplacement Fabrics, Kluwer Academic Publishers, Dordrecht (1997), pp. 95-112.

Brun et al., 1990 J.P. Brun, D. Gapais, J.P. Cogné, P. Ledru and J.L. Vigneresse, The Flamanville granite (NW France): an unequivocal example of an expanding pluton, GeologicalJ oumal 25 (1990), pp. 271-286.

Burg and Matte, 1978 J.P. Burg and P. Matte, A cross section through the French Massif Central and the scope of its Variscan geodynamic evolution, Zeitsc hrift der Deutschen Geologisc hen Gesellsc haft 129 (1978), pp. 429-460.

Burg et al., 1994 J.P. Burg, J. Van Den Driessche and J.P. Brun, Syn- to postthickening extension in the Variscan Belt of Western Europe: modes and structural consequences, Géologie de la France 3 (1994), pp. 33-51.

Couturié, 1977 J.P. Couturié, Le massif granitique de la Margeride (M.C.F.). Etude pétrographique, géochimique et structurale. Exemple de différenciation par gravité dans les roches granitiques. Evolution régionale de la croûte au cours de l'orogène hercynien, Annales de l'Université de Clemont-Ferrand 62 (1977) 335pp.

Couturié and Caen-Vachette, 1980 J.P. Couturié and M. Caen-Vachette, Age westphalien des leucogranites recoupant le granite de la Margeride, Comptes Rendus de l'Aca démie des Sciences 291 D (1980), pp. 43-45.

Couturié et al., 1979 J.P. Couturié, M. Caen-Vachette and Y. Vialette, Age namurien d'un laccolite granitique différencié par gravité: le granite de la Margeride (M. C. F.), Comptes Rendus de l'Aca démie des Sciences 289 D (1979), pp. 449-452. 
Cruden et al., 1999 A.R. Cruden, O.T. Tobisch and P. Launeau, Magmatic fabric evidence for conduit-fed emplacement of a tabular intrusion: Dinkey Creek Pluton, central Sierra Nevada batholith, California, J oumal of Geophysical Research 104 B5 (1999), pp. 10511-10530.

De Goër de Hervé et al., 1994 A. De Goër de Hervé, B. Briand, J.P. Couturié, A. Delpuech, B. Doche, A. Fel, J. Makhoul, F. Mercier-Batard and B. Michaëly, Carte géologique de la France au 1/50000, feville Nasbinals, Bureau de Recherches Géologiques et Minières, Orléans, France (1994).

Downes et al., 1997 H. Downes, A. Shaw, B.J. Williamson and M.F. Thirlwall, Sr, $\mathrm{Nd}$ and $\mathrm{Pb}$ isotopic evidence for the lower crustal origin of Hercynian granodiorites and monzogranites, Massif Central, France, Chemic al Geology 136 (1997), pp. 99-122.

Duthou et al., 1984 J.L. Duthou, J.M. Cantagrel, J. Didier and Y. Vialette, Paleozoic granitoids from the French Massif Central: age and origin studied by ${ }^{87} \mathrm{Rb} /{ }^{87} \mathrm{Sr}$ system, Physic s of the Earth and Planetary Interiors 35 (1984), pp. 131144.

Faure, 1995 M. Faure, Late orogenic carboniferous extensions in the Variscan French Massif Central, Tectonics 14 (1995), pp. 132-153.

Faure et al., 1992 M. Faure, J. Pons and J.F. Babinault, Le pluton du Pont-deMontvert: un granite syntectonique extravasé vers l'Est pendant le désépaississement crustal varisque du Massif Central français, Comptes Rendus de l'Aca démie des Sciences 315 (1992), pp. 201-208.

Faure et al., 1997 M. Faure, C. Leloix and J.Y. Roig, L'évolution polycyclique de la chaîne hercynienne, Bulletin de la Société géologique de France 168 (1997), pp. 695-705.

Faure et al., 1999 M. Faure, X. Charonnat and A. Chauvet, Schéma structural et évolution tectonique du domaine para-autochtone cévenol de la chaîne 
hercynienne (Massif central français), Comptes Rendus de l'Académie des Sciences 328 (1999), pp. 401-407.

Faure et al., 2001 M. Faure, X. Charonnat, A. Chauvet, Y. Chen, J.-Y. Talbot, G. Martelet, G. Courrioux, P. Monié and J.-P. Milesi, Tectonic evolution and ore bearing fluids circulation in the Cévennes para-autochthonous domain of the Hercynian Belt (French Massif Central), Bulletin de la Société Géologique de France 172 (2001), pp. 687-696.

Faure et al., 2004 M. Faure, P. Ledru, J.M. Lardeaux and P. Matte, Paleozoic orogenies in the French Massif Central. A cross-section from Béziers to Lyon. 15-19 Août 2004, Pre-congress Excursion B22, 24th Intemational Geological Congress, Florence, August (2004) 48pp.

Feybesse et al., 1995 J.L. Feybesse, J.P. Couturié, P. Ledru and V. Johan, Les granites de la Margeride, de Chambon-le-Château et de Saint-Christophed'Allier (Massif Central): des laccolites synchrones des derniers stades de l'épaississement varisque, Géologie de la France 1 (1995), pp. 27-45.

Gleizes et al., 1997 G. Gleizes, D. Leblanc and J.L. Bouchez, Variscan granites of the Pyrenees revisited: their role as syntectonic markers of the orogen, Terra Nova 9 (1997), pp. 38-41.

Hrouda, 1982 F. Hrouda, Magnetic anisotropy of rocks and its application in geology and geophysics, Geophysic al Surveys 5 (1982), pp. 37-82.

Isnard, 1996 Isnard, H., 1996. Datation par la méthode U-Pb sur monazites des granites du Mont Lozère et de l'Est de la Margeride (laccolites de Chambonle-Château et de St-Christophe d'Allier): contribution à I'histoire posttectonique du Massif Central Français. Master thesis, Université de Montpellier II, 55pp. 
Jelinek, $1978 \vee$ V. Jelinek, Statistical processing of anisotropy of magnetic susceptibility measured on groups of specimens, Studia Geophyzika et Geodetika 22 (1978), pp. 50-62.

Jelinek, $1981 \mathrm{~V}$. Jelinek, Characterization of the magnetic fabric of rocks, Tec tonophysics 79 (1981), pp. 563-567.

Labove, 1982 Labove, M., 1982. Etude structurale du massif de la Margeride. $\mathrm{PhD}$ thesis, Université de Clermont-Ferrand, 140pp.

Lafont and Respaut, 1988 J.M. Lafont and J.P. Respaut, Géochronologie U-Pb et leucogranites varisques: cas des massifs de Grandrieu (Lozère) et de la Porcherie (Limousin), Massif Central français, Bulletin de Minéralogie 3 (1988), pp. 225-237.

Lardeaux et al., 2001 J.M. Lardeaux, P. Ledru, I. Daniel and S. Duchene, The Variscan French Massif Central-a new addition to the ultra-high pressure metamorphic "club": exhumation processes and geodynamic consequences, Tectonophysics 332 (2001), pp. 143-167.

Ledru et al., 1989 P. Ledru, J.M. Lardeaux, D. Santallier, A. Autran, J.M. Quénardel, J.P. Floc'h, G. Lerouge, N. Maillet, J. Marchand and A. Ploquin, Où sont les nappes dans le Massif central français?, Bulletin de la Société géologique de France 5 (1989), pp. 605-618.

Ledru et al., 1994 P. Ledru, S. Costa and H. Echtler, The Massif Central: structure. In: J.D. Keppie, Editor, Pre-Mesozoic Geology in France and Related Areas, Springer, Berlin (1994), pp. 276-288.

Ledru et al., 2001 P. Ledru, G. Courrioux, C. Dallain, J.M. Lardeaux, J.M. Montel, O. Vanderhaeghe and G. Vitel, The Velay dome (French Massif Central): melt generation and granite emplacement during orogenic evolution, Tec tonophysic s 342 (2001), pp. 207-237. 
Martelet et al., 1999 G. Martelet, M. Diament and C. Truffert, Un lever gravimétrique détaillé dans les Cévennes: apport à l'imagerie crustale (programme GéoFrance 3D-Massif central), Comptes Rendus de I'Académie des Sciences de Paris 328 (1999), pp. 727-732.

Mattaver and Etchecopar, 1977 M. Mattaver and A. Etchecopar, Argumentation en faveur de chevauchements de type himalayen dans la chaîne hercynienne du Massif Central français, Colloque Intemational CNRS 268 (1977), pp. 261-267.

Matte, 1986 P. Matte, Tectonics and plate tectonics model for the Variscan belt of Europe, Tectonophysics 126 (1986) (2-4), pp. 329-374.

Monié et al., 2000 Monié, P., Respaut, J.P., Brichaud, S., Bouchot, V., Faure, M., Roig, J.Y., 2000. ${ }^{40} \mathrm{Ar} /{ }^{39} \mathrm{Ar}$ and U-Pb geochronology applied to Au-W-Sb metallogenesis in the Cévennes and Châtaigneraie districts (Southern Massif Central, France). In: Orogenic Gold Deposits in Europe, Document BRGM 297. Bureau de Recherches Géologiques et Minières, Orléans, France, pp. 77-79.

Neves et al., 2003 S.P. Neves, A.M.B. Araujo, P.B. Correia and G. Mariano, Magnetic fabrics in the Cabanas Granite (NE Brazil): interplay between emplacement and regional fabrics in a dextral transpressive regime, Joumal of Structural G eology 25 (2003), pp. 441-453

Olivier and Améglio, 2002 P. Olivier and L. Améglio, Structure et mise en place en régime décrochant puis rotation tardi-magmatique des plutons granitiques hercyniens du Veinazès et de Marcolès (Châtaigneraie, Massif central français), Bulletin de la Société géologique de France 173 (2002), pp. 207-218.

Paterson et al., 1989 S.R. Paterson, R.H. Vernon and O.T. Tobisch, A review of criteria for the identification of magmatic and tectonic foliations in granitoids, J oumal of Struc tural G eology 11 (1989), pp. 349-363. 
Paterson et al., 1998 S.R. Paterson, T.K. Fowler Jr, K.L. Schmidt, A.S. Yoshinobu, E.S. Yuan and R.B. Miller, Interpreting magmatic fabric patterns in plutons, Lithos 44 (1998), pp. 53-82.

Pétrequin, 1979 Pétrequin, M., 1979. Etude gravimétrique du massif de la Margeride et de sa bordure orientale. PhD thesis, Université de Montpellier, $95 \mathrm{pp}$.

Pin, 1979 Pin, C., 1979. Géochronologie U-Pb et microtectonique des séries métamorphiques antéstéphaniennes de l'Aubrac et de la région de Marvejols (Massif Central). PhD thesis, Université de Montpellier, 205pp.

Respaut, 1984 Respaut, J.P., 1984. Géochronologie et géochimie isotopique $\mathrm{U}-\mathrm{Pb}$ de la minéralisation uranifère de la mine des Pierres Plantées (Lozère) et de son encaissant: le massif granitique de la Margeride. PhD thesis, Université de Montpellier, 122pp.

Talbot, 2003 Talbot, J.Y., 2003. Apport des études ASM et gravimétriques des plutons cévenols à la caractérisation structurale de l'évolution tardihercynienne du Massif Central. PhD thesis, Université d'Orléans, 296pp.

Talbot et al., 2000 J.Y. Talbot, Y. Chen, M. Faure and W. Lin, AMS study of the Pont-de-Montvert-Borne porphyritic granite pluton (French Massif Central) and its tectonic implications, Geophysical Joumal Intemational 140 (2000), pp. 677-686.

Talbot et al., 2004 J.Y. Talbot, G. Martelet, G. Courrioux, Y. Chen and M. Faure, Emplacement in an extensional setting of the Mont Lozère-Borne granitic complex (SE France) inferred from comprehensive AMS, structural and gravity studies, J oumal of Struc tura I Geology 26 (2004), pp. 11-28.

Tarling and Hrouda, 1993 D.H. Tarling and F. Hrouda, The Magnetic Anisotropy of Rocks, Chapman \& Hall, London (1993) 220pp. 
Van de Meulebrouck, 1983 Van de Meulebrouck, J., 1983. Reconnaissance géophysique des structures crustales de deux segments de chaîne de collision: le Haut Allier (Massif Central français) et le Sud du Tibet (Himalaya). PhD thesis, Université de Montpellier, 137pp.

Vernon, 2000 R.H. Vernon, Review of microstructural evidence of magmatic and solid-state flow, Electronic Geosciences 5 (2000) (2).

Vigneresse, 1990 J.L. Vigneresse, Use and misuse of geophysical data to determine the shape at depth of granitic intrusions, Geological Joumal 25 (1990), pp. 249-260.

Vigneresse, 1995 J.L. Vigneresse, Control of granite emplacement by regional deformation, Tec tono physic s 249 (1995), pp. 173-186.

Vigneresse and Bouchez, 1997 J.L. Vigneresse and J.L. Bouchez, Successive granitic magma batches during pluton emplacement: the case of Cabeza de Araya (Spain), J oumal of Petrology 38 (1997), pp. 1767-1776 